\title{
OSMANLI SOSYAL HAYATINDA MOLLALAR: 18. VE 19. YY. DIYYARBEKİR ÖRNEĞİ
}

\section{Ümit Güler*}

\section{$\ddot{O} \mathbf{z}$}

Molla tabiri, Osmanlı öncesinde olduğu gibi Osmanlı'da da ilmi bir unvan olarak kullanılmış ve bu bağlamda muhtelif birçok grubu ifade edebilmiştir. 18. ve 19. yüzyıl Diyarbekir (Amid) şer'iyye sicilleri esas alınarak hazırlanan bu çalışmada, ilgili dönem Diyarbekir'inde genel olarak medrese mezunlarına molla denildiği ortaya çıkmıştır. Araştırmada mollaların, ilgili dönem sicillerinde oldukça yoğun ve belirgin biçimde yer aldıkları tespit edilmiştir. Bu sonucun ortaya çıkmasında medrese tahsiline duyulan ilginin yanı sıra mollalara toplum tarafından takdir edilen büyük saygı ve değerin belirleyici bir rolünün olduğu söylenebilir. Mollaların bu dönemde neredeyse hiçbir suç hadisesine karışmamış olmaları genel itibariyle kendileri için takdir edilen saygı ve değere muvafik bir yaşam tarzına sahip olduklarına işaret etmiş̧tir. $\mathrm{Bu}$ durum, din ve eğitim hizmetlerinde bulunan veya esnaf ve zanaatkârlık mesleklerini icra eden mollaların geneli için geçerlidir. Mollaların \%31.6'sının esnaf ve zanaatkârlıkla iştigal etmesine rağmen sonucun bu şekilde ortaya çıması, medrese kurumlarının birey ve toplum kalitesini yükseltmeye yönelik başarısını yansıtmaktadır. Bu araştırma, esnaf ve zanaatkârlar da dâhil olmak üzere genel itibariyle tüm meslek gruplarındaki mollaların, toplum hayatını ıslah edici ve geliştirici bir rol oynadıklarını; toplum nezdinde ciddi bir saygınlıklarının bulunduğunu ve bu saygınlığa muvafik bir hayat tarzına sahip oldukların belgelere dayalı olarak ortaya koymaktadır.

Anahtar Kelimeler: Molla, Diyarbekir, Osmanl1, Medrese, Sosyal Tarih

\section{MULLAHS IN OTTOMAN SOCIAL LIFE: XVIII AND XIX CENTURY DIYARBEKIR EXAMPLE}

\begin{abstract}
The expression mullah was used as a scientific title both before and during Ottoman rule; and it is possible that it might refer to various groups within this context. In this study, which was prepared based on court records of XVIII and XIX century Diyarbekir (Amid), it turned out that the madrasah graduates in general were called as mullahs during the abovementioned period Diyarbekir. In the study, it was established that mullahs were mentioned intensionally and markedly in the court records of the time. It
\end{abstract}

Article Types/Makale Türü: Research Article/Araştırma Makalesi

Received/Makale Geliş Tarihi:22/06/2019, Accepted/Kabul Tarihi: 25/07/2019

Doi: $10.26791 /$ sarkiat.580229

* Dr. Öğr. Üyesi, Batman Üni. İslami İlimler Fakültesi İslam Tarihi Ana Bilim Dalı, umit.guler@batman.edu.tr

ORCID ID: https://orcid.org/0000-0002-0828-4197 
can be said that not only the interest given to madrasah education but also great respect and value appraised for mullahs by the community played important role in emergence of the result. That the mullahs did not interfere in almost any crime events during that time points out that they, in general, led a life style in line with respect and value appraised by the society. This is valid for nearly all mullahs who conducted religious and educational services and who were in the professions of trades and craftsmen. Although $31.6 \%$ of the mullahs were engaged in trades and craftsmanship, this result reflects the fact that success of madrasah institutions improved the quality of individuals and community. This study, based on records, demonstrates that mullahs in all professional groups, including tradesmen and artisans, played a role of improving and bettering community life, and that they achieved a serious respect throughout the society, and that they led a life style that was compatible with this respect.

Keywords: Mullah, Diyarbekir, Ottoman, Madrasah, Social History

\section{GíRiş}

Molla tabiri köken itibariyle Arapça olup "efendi, sahip, âmir" anlamını ifade eden "mevlâ" kelimesinden gelmekte ve kelimenin eş anlamlı olarak "monla", "munla" veya "mulla" biçimleri bulunmaktadır. Bu unvanı alan kişinin bilgi birikiminden dolayı mollanın "doldurmak" anlamındaki "mel"” kökünden geldiği de zayıf bir ihtimal olarak ifade edilmektedir. ${ }^{1}$ Kelime, sözlük anlamı olarak ise âlim, fâdıl ve fakih anlamlarına gelmektedir. $^{2}$

Molla tabiri, Osmanlı öncesinde olduğu gibi Osmanlı'da da ilmi bir unvan olarak kullanılmış ve birçok farklı zümreyi ifade edebilmiştir. ${ }^{3}$ Örneğin Osmanlı' da bu unvan, müderrislikten sonraki mevleviyet pâyesi denilen dereceye ulaşan büyük âlimlerle Süleymaniye müderrislerinden mansıp alarak 300 akçelik kadılık mesleğine geçen, 300 akçeden yukarı mevleviyete ${ }^{4}$ tayin edilen birinci sınıf kadılara verilmektedir. Bununla birlikte İstanbul kadısına daha çok "İstanbul efendisi" denildiği, diğer vilayet kadıları için de bulundukları şehre göre örneğin "Edirne mollası" veya "Diyarbekir mollası" ifadelerinin kullanıldığ 1 bilinmektedir. ${ }^{5}$ XVI. yüzyılın ikinci yarısından itibaren ilmiye sınıfında "zâdegân" diye anılan ulemâ neslinin ortaya çıkmasıyla "beşik ulemâsı" denilen grup türemiş ve bunlara "molla bey" unvanı verilmiştir. ${ }^{6}$

1 Hamid Algar, "Molla", Türkiye Diyanet Vakfi İslâm Ansiklopedisi (İstanbul: TDV Yayınları, 2005), 30: 238 .

2 Mehmet Zeki Pakalın, "Molla”, Osmanlı Tarih Deyimleri ve Terimleri Sözlüğü, (İstanbul: Milli Eğitim Basımevi, 1993), 2: 549.

3 Hamid Dabashi, "Mullah", The Oxford Encyclopedia of the Modern Islamic World, ed. John L. Esposito - v.dğr. (New York: Oxford University, 1995), 3: 177; J. Calmard, "Mollā", The Encyclopedia of Islam, (Leiden: E.J. Brill, 1980), 7: 221-222.

4 Osmanlı ilmiye teşkilâtında yüksek dereceli kadılıklar için kullanılan bir terimdir. Geniş bilgi için bk. Fahri Unan, "Mevleviyet", Türkiye Diyanet Vakfi İslâm Ansiklopedisi (Ankara: TDV Yayınları, 2004), 29: 467.

5 Algar, "Molla", 30: 238; Ayrıca bk. Hüseyin Atay "Fatih Süleymaniye Medreseleri Ders Programları ve İcazetnameler", Vakıflar Dergisi 13 (1981): 176; "Diyarbekir mollası" tabiri için bk. DŞS, 3754, 26a-1.

6 Algar, "Molla", 30: 239; Ayrıca bk. İsmail Hakkı Uzunçarşılı, Osmanlı Devletinin İlmiye Teşkilâtı, (Ankara: Türk Tarih Kurumu Basımevi, 1988), 264. 
Osmanlı'nın son dönemlerinden itibaren molla tabirinin medrese öğrencileri için de kullanılmaya başladığı, ayrıca kadınlar arasında Kur'an ve Mevlid okuma gibi dinî hizmetleri yerine getiren hanımların isimlerinin sonuna bu kelimenin eklendiği de zikredilir. ${ }^{7}$ Bunların yanı sıra ehil olan mollaların Osmanlı medreselerinde müderrislik yapabildikleri de belirtilir. ${ }^{8}$ Görüldüğü gibi molla unvanının geniş bir kullanım alanı vardır. Ancak mollalara dair zikredilen bu bilgiler noksanlık ihtiva etmektedir. Zira 18. ve 19. yüzyıl Diyarbekir (Amid) şer'iyye sicilleri üzerine yapmış olduğumuz incelemede molla veya monla unvanının, dinî bir görev icra etsin veya etmesin bilumum medrese mezunları için de kullanıldığı anlaşılmıştır. Bununla beraber şark vilayetlerindeki medrese mezunu din adamlar. ${ }^{9}$ ve şark medreselerinde ${ }^{10}$ görev icra eden hocaların da molla olarak adlandırıldıkları bilinmektedir. ${ }^{11}$

Osmanlı'daki molla kurumuna dair verilen bilgilerdeki eksikliklerin, ${ }^{12}$ bu konunun henüz yeterince incelenmemiş olmasından kaynaklandığı açıktır. Zira mevzu üzerine yapmış olduğumuz araştırmada, Osmanlı'daki mollalığın incelendiği herhangi bir çalışmaya rastlamış değiliz. Bu durum Osmanlı sosyal tarih araştırmaları açısından ciddi bir eksiklik olup mevzu üzerine müstakil ve kapsamlı araştırmalara ihtiyaç duyulduğu aşikârdır. Mezkûr ihtiyaçtan hareketle bu çalışmada, Osmanlı sosyal hayatında mollalar 18. ve 19. yüzyıl Diyarbekir (Amid) şer‘iyye sicilleri ışı̆̆ında incelenmiştir.

Diyarbakır şehrinin eski adı "Amida" olup bu isim İslami dönemde “Amid" şeklinde kullanılmıştır. Diyarbakır isminin de Bekir b. Vâil kabilesinin yayıldığı toprakları ifade etmek üzere "Diyâr Bekr" veya "Diyâr-1 Bekr" olarak ortaya çıktığı, tam olarak ne zamandan beri kullanıldığı kesin olarak bilinmemekle birlikte M. 8. yüzyıldan itibaren kaynaklarda geçtiği ifade edilmektedir. ${ }^{13} 1515$ yılında başlayan Osmanlı hâkimiyeti döneminde bu isim "Diyarbekir" şeklini alarak eyaletin genelini ifade ederken, "Amid" ismi de bugünkü Diyarbakır merkezi için kullanılmıştır. ${ }^{14}$

Roma ve Bizans dönemlerinde eyalet merkezi olarak idari açıdan büyük önem atfedilen Diyarbakır, M. 639 yılında Müslümanlar tarafından fethedildikten sonra kültürel, idari

7 Algar, "Molla", 30: 238.

8 Ahmet Kamil Cihan, "Fatih Dönemi İlim Hayatı ve Hocazâde", Uluslararası Hocazâde Sempozyumu Bildirileri (Bursa, 22-24 Ekim 2010), ed. Tevfik Yücedoğru v.dğr. (Bursa: Bursa Büyükşehir Belediyesi Yayınları, 2011), 70.

9 17. yüzyılın ortalarında Diyarbekir'i ziyaret eden Evliya Çelebi, burada din bilginlerine "monla" dendiğini aktarmaktadır. bk. Evliya Çelebi, Evliya Çelebi Seyahatnamesi, haz. Seyit Ali Kahraman - Yücel Dağlı, (İstanbul: Yapı Kredi Yayınları, 2010), 4: 52; Günümüzde de Doğu ve Güneydoğu illerinde medresede yetişmiş din adamları molla (mela) olarak adlandırılmaktadır. bk. Martin Van Bruinessen, A ̆ga, Şeyh, Devlet, trc. Banu Yalkut (İstanbul: İletişim Yayınları, 2011), 310. Ayrıca bk. Halil Çiçek, Şark Medreselerinin Serencamı, (İstanbul: Beyan Yayınları, 2009), 29 vd.

10 Şark Medreseleri hakkında geniş bilgi için bk. Çiçek, Şark Medreselerinin Serencamı, 27 vd.; Osmanlı medreseleri ile şark (Doğu-Güneydoğu) medreseleri arasındaki farklılıklar için bk. Sabahattin Bala, Bir Ĕ̆itim Kurumu Olarak Şark Medreseleri (Mardin Yöresi Örneği) (Yüksek Lisans Tezi, Dicle Üni., 2012), 69.

11 Tahir Pekasil, "Toplumsal Statü Göstergesi Olarak Dinî Otorite Tipleri: Cizre Örneğinde Şeyh, Molla ve Seyyidler”, Uluslararası Bilim Düşünce ve Sanatta Cizre Sempozyumu Bildirileri 2012, ed. M. Nesim Doru (İstanbul: 2012), 141; Necdet Subaşı, "Şeyh, Seyyid ve Molla -Doğu ve Güneydoğu Anadolu Örneğinde Dinsel İtibarın Kategorileri” İslâmiyât 2/3 (1999), 136.

12 Algar, "Molla", 30: 238.

13 Nejat Göyünç, "Diyarbakır”, Türkiye Diyanet Vakfi İslâm Ansiklopedisi (İstanbul: TDV Yayınları, 1994), 9: 465.

14 İbrahim Yılmazçelik, XIX. Yüzyılın İlk Yarısında Diyarbakır (1790-1840), (Ankara: Türk Tarih Kurumu Yay., 2014), 12. 
ve ekonomik yönden oldukça önemli bir merkez olmuş ve bu nitelikleri Osmanlı hâkimiyeti ${ }^{15}$ döneminde daha da gelişmiştir. ${ }^{16}$

Diyarbekir (Amid) şehri, mezkûr nitelikleri sebebiyle araştırma konumuz olan mollaların, Osmanlı sosyal hayatındaki yerlerinin incelenmesi açısından tarihsel ve sosyolojik olarak oldukça elverişli bir bölgedir. Zira yukarıda da değinildiği gibi Diyarbekir, Osmanlı döneminde önemli bir kültür merkezi niteliğindedir. ${ }^{17}$ Öyle ki şehrin bu niteliği İstanbul'dan gönderilen döneme ait bir belgeye "...Medîne-i Amid kadîmden [beru] menba'-1 ulemâ vü sulehâ olup..." ifadeleriyle yansımıştır. ${ }^{18}$ Yine bu dönemde şehrin lakabının da "Dârül-Fahr"19 olduğu ifade edilir. ${ }^{20}$

1654-1655 yılında şehri ziyaret eden Evliya Çelebi, Diyarbekir'de her caminin birer ikişer medresesi olduğunu kaydetmiştir. ${ }^{21}$ Günümüzde bu bilgiyi teyit edecek bilgi ve belgelere ulaşılamamış olsa da Çelebi'nin bu aktarımı, şehrin medrese zenginliğine işaret etmektedir. Nitekim Diyarbakır Osmanlı hâkimiyetine geçtiği zaman şehirde önceki dönemlerden kalma on iki medresenin olduğu, ${ }^{22}$ Osmanlı döneminde de sayısı net olmamakla beraber yirmiden fazla yeni medresenin açıldığı ve toplamda 35 civarı medresenin Osmanlı eğitim sistemine tabi olarak faaliyet gösterdiği belirtilmektedir. ${ }^{23}$ Her ne kadar Osmanlı eğitim kurumlarının 16. yüzyılın sonlarından itibaren zaman içerisinde gerilemesi söz konusu olsa da ${ }^{24}$ 19. yüzyıl Diyarbekir'i üzerine yapılan araştırmalar bu dönemde de şehrin medrese ve kütüphaneler yönünden oldukça önemli bir kültür merkezi olduğuna vurgu yapmaktadır. ${ }^{25}$

Şehrin medreselerinin zengin oluşunda dindar kimselerin ilgi ve teveccühünün de etkisinin olduğu muhtemeldir. Nitekim Evliya Çelebi meşhur eserinde şehir ahalisinin

15 Diyarbakır'ın Osmanlı tarafından ele geçirilmesi zorla olmamış, bilakis şehir ahalisinin ittifak ve desteğiyle gerçekleşmiştir. Geniş bilgi için bk. Ali Emirî Efendi, Osmanlı Doğu Vilâyetleri, haz. Abdulkadir Yuvalı - Ahmet Halaçoğlu (İstanbul: Babıali Kültür Yayıncılığı, 2015), 82-95; İbrahim Özcoşar, "Bir İslam ve Osmanlı Şehri Olarak Diyarbakır/Amid", Osmanlı'dan Günümüze Diyarbakır, ed. İbrahim Özcoşar v.dğr. (İstanbul: Ensar Yay., 2018): 6.

16 Yilmazçelik, XIX. Yüzyılın İlk Yarısında Diyarbakır (1790-1840), 17; Bahaeddin Yediyıldı, “Osmanlı Öncesi Diyarbakır'ına Genel Bir Bakış”, Osmanlı'dan Cumhuriyet'e Diyarbakır, ed. Bahaeddin Yediyıldız - Kerstin Tomenendal (Ankara: Diyarbakır Valiliği, 2010), 1: 36; Göyünç, "Diyarbakır”, 464-469. Diyarbakır ve çevresinin Müslümanlaşma süreci hakkında geniş bilgi için bk. Mehmet Azimli, Diyarbakır ve Çevresinin Müslümanlaşma Süreci, (Konya: Çizgi Kitapevi Yay., 2010), $16 \mathrm{vd.}$

17 Yilmazçelik, XIX. Yüzyılın İlk Yarısında Diyarbakır (1790-1840), 23; Abdurrahman Acar, "Diyarbakır Medreseleri ve Osmanlı Eğitim Sistemi İçerisindeki Yerleri, Osmanlı'dan Cumhuriyet'e Diyarbakır, ed. Bahaeddin Yediyıldız - Kerstin Tomenendal (Ankara: Diyarbakır Valiliği, 2010), 1: $124 \mathrm{vd}$.

18 DŞS, 3698, 22b-1.

19 "Övünç Yurdu"

${ }^{20}$ Mehmet İpşirli, "Lakap”, Türkiye Diyanet Vakfi İslâm Ansiklopedisi (Ankara: TDV Yayınları, 2003), 27: 64.

21 Evliya Çelebi, Evliya Çelebi Seyahatnamesi, 4: 42.

${ }^{22}$ Acar, "Diyarbakır Medreseleri ve Osmanlı Eğitim Sistemi İçerisindeki Yerleri”, 1: 126.

23 Acar, "Diyarbakır Medreseleri ve Osmanlı Eğitim Sistemi İçerisindeki Yerleri”, 1: 138; Mezkûr rakam devlet genelinde yaşanan aksaklıkların etkisiyle zaman içerisinde azalma göstermiş ve yirminci yüzyılın başlarında on bire kadar düşmüştür. bk. Acar, "Diyarbakır Medreseleri ve Osmanlı Eğitim Sistemi İçerisindeki Yerleri”, 139. Diyarbekir medreseleri hakkında geniş bilgi için bk. Acar, "Diyarbakır Medreseleri ve Osmanlı Eğitim Sistemi İçerisindeki Yerleri”, 1: 111-153.

${ }^{24}$ Uzunçarşıl1, Osmanlı Devleti'nin Ilmiye Teşkilatı, 67.

25 Yilmazçelik, XIX. Yüzyılın İlk Yarısında Diyarbakır (1790-1840), 112. 
dindar kimliğine özel olarak vurguda bulunmuştur. ${ }^{26}$ Haddizatında medrese bitiren kimselerin molla olarak adlandırılması, halk tarafından kendilerine saygı ve değer atfedilmesi ve toplum içerisinde etkin olmaları, şehrin dindar niteliğini yansıtmaktadır. Binaenaleyh mollaların sosyal hayatta aktif olmalarıyla da sicillerdeki görünümlerinin arttığı ve belirginleştiği söylenebilir. Bu durum mollaların toplumla kurdukları ilişkilerin nitelik ve niceliğinin incelenmesi bakımından oldukça elverişli bir sosyolojik zemin meydana getirmektedir. Bunun yanı sıra şehrin, dinî zümreler itibariyle Anadolu'nun diğer şehirlerine nispetle daha çeşitli olması, ${ }^{27}$ mollaların gayrimüslimlerle olan ilişkilerinin gözlemlenmesi bakımından da elverişlilik arz etmektedir.

Yukarıda sözü edilen ilişkilerin gün yüzüne çıkarılması bakımından şer‘iyye sicilleri son derece önemli bir kaynak niteliğindedir. Zira Osmanlı toplumunun sosyal tarihine 1şık tutması açısından en önemli kaynaklar şer'iyye sicilleridir. ${ }^{28}$ Bu noktadan hareketle şimdiye kadar müstakil herhangi bir araştırmada incelenmemiş olan "Osmanlı sosyal hayatında mollalar" konusu Diyarbekir örneğinde ele alınacaktır. Araştırmanın orjinalitesini sağlamak amacıyla mevzu, tarih araştırmalarında birinci elden kaynak olma özelliği taşıyan, şehrin döneme ait şer'iyye sicilleri temelinde incelenecektir. Çalışmanın amacı, sicil kayıtlarına yansıyan görünümlerden hareketle 18. ve 19. yüzyıl Diyarbekir'indeki mollaların sosyal hayatlarına ışık tutmaktır.

\section{Mollaların Ailevi İlişkileri}

İncelenen belgelerde çok sayıda kişinin kendi adında veya babasının adında mollamonla unvanına rastlanmıştır. Kadı sicillerinde baba ve oğul isimlerinin ve varsa unvanlarının zikredilmesiyle molla unvanına sahip kişilerin, babalarının unvanına bağlı olmaksızın kendi tahsilleriyle bunu kazandıkları anlaşılmaktadır. Daha yalın bir ifadeyle bu dönemde babadan oğula geçen bir mollalık unvanı yoktur. Bunun yanı sıra mollaların büyük çoğunluğunun babası molla değildir ve onlar bu unvanı, kendi tahsilleriyle elde etmişlerdir. Burada esas önem arz eden husus, mollalığın geçişken ve tüm Müslümanlara açık bir toplumsal grup olmasıdır. Şöyle ki ilgili sicillerde molla unvanı olmayan kişilerin evlatları bu unvanı taşıyabilmişsen ${ }^{29}$ kimi zaman da mollalık

26 “Gerçekten bu vilâyetin umumen zerafeti gibi güzellik sahibi olmaz, derler. Bütün halkı mü’min, muvahhid, temiz inançlı, tevhid ehli ve dindar adamlardır. Kadın kısmı gayet edepli, Râbia-i Adeviyye derecesinde perde ehli, dindar ve güzellik sahibi kadınları vardır.” bk. Evliya Çelebi, Evliya Çelebi Seyahatnamesi, 4: 72.

27 Kenan Ziya Taş, Tarih Işığında Güneydoğu ve Diyarbakır, (Ankara: Berikan Yayınevi, 2012), 21; Jelle Verhei - Suavi Aydın, "Diyarbekir Vilâyetinde Etnik-Dinî Gruplar, Yerel Güçler ve Osmanlı Devleti Üzerine Birkaç Not (1800-1870)", Osmanlı Döneminde Diyarbekir'de Toplumsal İlişkiler (1870-1915), ed. Joost Jongerden - Jelle Verheij, çev. Ayşen Gür (İstanbul: İstanbul Bilgi Üniversitesi Yayınları, 2015), 15; Bu dönemde Diyarbekir'de bulunan başlıca dinî gruplar Müslüman, Katolik, Protestan, Ortodoks, Yahudi, Yezidi ve Keldaniler olarak belirtilebilir. Geniş bilgi için bk. Taş, Tarih Işı̆̆ında Güneydoğu ve Diyarbakır, 38.

28 Ahmet Akgündüz, Şeri'yye Sicilleri, (İstanbul: Türk Dünyası Araştırmaları Vakfı, 1988), 1: 12; Ayrıca bk. Osman Çetin, Sicillere Göre Bursa'da Ihtida Hareketleri ve Sosyal Sonuçları (14721909), (Ankara: Türk Tarih Kurumu Basımevi, 1994), IX; Yunus Uğur, "Şer'iyye Sicilleri”, Türkiye Diyanet Vakfi Íslâm Ansiklopedisi (İstanbul: TDV Yayınları, 2010), 39: 8; Şer'iyye sicilleri hakkında geniş bilgi için bk. İsmail Hakkı Uzunçarşılı, "Şer‘î Mahkeme Sicilleri”, Ülkü Halkevleri Dergisi 5/29 (Temmuz 1935): 365-368; T. Mümtaz Yaman, "Şer'î Mahkeme Sicilleri”, Ülkü Halkevleri Dergisi 12/68 (İlk Teşrin 1938): 153-164.

29 Örnek için bk. DŞS, 3773, 26b-2; DŞS, 3773, 13b-2; DŞS, 3773, 27b-2; DŞS, 3773, 29a-2; DŞS, 3773, 40a-3; DŞS, 3773, 56a-1; DŞS, 3754, 170a-1. 
unvanına sahip kişilerin evlatlarının bu unvanı olmamıştır. ${ }^{30}$ Bununla beraber baba ve oğulun her ikisinin molla olduğu aileler oldukça azdır. ${ }^{31}$ İlgili döneme ait kadı sicilleri üzerinde yapılan incelemede mollalara ait 98 adet tereke kaydı tespit edilmiştir. Bu tereke kayıtlarına göre sadece 5 mollanın (\%5.1) babasının da bu unvana sahip olduğu görülmüştür. Dolayısıyla mollalığın Müslüman toplumun her kesimine açık toplumsal bir grup olduğu söylenebilir.

Mollaların taraf oldukları veraset davalarından veya babalarına ait tereke kayıtlarından, ailelerinin zengin olanlarının az olduğu gözlenmiştir. $\mathrm{Bu}$ kayıtlardan hareketle mollaların ekseriyetle ekonomik olarak orta düzey ve az da olsa alt düzey ailelerden geldikleri söylenebilir. Mollaların babalarının isimlerinin önünde kimi zaman penbeci (pamukçu), ${ }^{32}$ berber ${ }^{33}$ neccâr (marangoz) ${ }^{34}$ gibi mesleki unvanlara da rastlanmıştır. Bununla beraber mollaların da isimlerinin önünde muhtelif birçok mesleğe dair unvanlar bulunabilmiştir. Mollaların meslekleriyle ilgili mevzuya ileride ayrıca temas edilecektir.

Mollalara ait tereke kayıtlarından onların evlendikleri kişilere ve çocuklarına dair oldukça değerli bilgiler edinilebilmiştir. Şimdi sırasıyla mollaların hanımlarına ve çocuklarına temas edilecektir. Sözünü ettiğimiz 98 adet tereke kaydının 89'unda mollaların hanımlarının isimleri zikredilmiştir. Geriye kalan dokuz terekeden de mollaların bekâr oldukları veya en azından bilinen varislerinin bulunmadığ anlaş1lmaktadır. Varisi bulunmayan üç mollanın medresede ikamet etmesi bekâr olduklarına işaret etmektedir. ${ }^{35}$

Mollaların genelde tek eşli oldukları görülmektedir. Zira 89 tereke kaydının 78'inde, dolayısıyla \%87.6'lık bir oranla tek eşliliğin hâkim olduğu görülür. 11 tereke kaydında ise birden fazla eş bulunmaktadır. Bu da \%12.3 gibi bir orana tekabül etmektedir. $\mathrm{Bu}$ evliliklerin 10'unda mollaların ikişer hanımı bulunurken birinde üç hanımın olduğu gözlenmiştir. Dolayısıyla mollalar tarafından yapılan çok evliliklerde genelde iki hanımdan fazlasının alınmadığı ortaya çıkmaktadır. ${ }^{36}$ Burada dikkati celbeden husus, mollaların tek eşlilik oranlarının genel ortalamanın üstünde olmasıdır. Zira 1787-1845 yılları arasında Diyarbekir'deki ailelerin evlilik durumlarının belirtildiği bir çalışmada, bu dönemde Müslümanlar arasında tek kadınla evlilik oranının \%78.58 olduğu görülür. ${ }^{37} \mathrm{Bu}$ da mollaların yaklaşık \%10 gibi bir oranla tek eşliliği daha fazla tercih ettiklerini ortaya koymaktadır. Dinî eğitim almış kişilerin tek eşliliği daha fazla tercih etmiş olmaları dikkat çekici bir bulgudur.

Tereke kayıtları mollaların evlenecekleri kişileri seçerken kendileri gibi molla zümresinden veya belirli bir zümreden mi yoksa normal insanlar arasından mı evlendikleri sorusuna 1şık tutmaktadır. Kayıtlarda isimleri geçen tüm hanımların baba isimleri kaydedilmiş olmasa da 87 kişinin baba ismi zikrolunmuştur. Bu kişilerin isimlerinde bulunan sifatlara bakıldığında sadece 5 hanımın (\%5.6) baba isminde molla ibaresinin olduğu gözlenmiştir. Dolayısıyla evlenilen kadınların molla ailelerinden

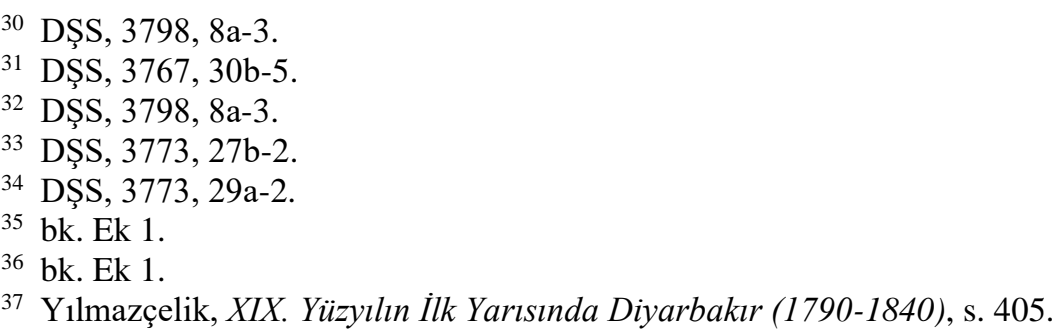


seçilmesi gibi bir sınırlamanın veya temayülün olmadığı söylenebilir. Bunların yanı sıra ilgili dönemde kimi Müslüman erkeklerin gayrimüslim kadınlarla evlenmelerine rağmen mollaların tamamının Müslüman kadınlarla evlendiklerini ayrıca ifade etmekte fayda vardır. Dolayısıyla mollaların bu konuda daha muhafazakâr oldukları anlaşılmaktadır.

Döneme ait kadı sicillerinden bu dönemde "başlık" uygulamasının cari ve yasal olduğu, mollaların da kimi zaman evlendikleri kızın babasına "başlık" adı altında bazı eşyalar verdikleri anlaşılmaktadır. ${ }^{38}$ Mahkeme, "başlık" olarak verilen bu eşyaların geri alınması amacıyla açılan bir davada davacıyı haksız bulmuş ve "başlık" kapsamında verilen eşyaların geri talep edilemeyeceğine hükmetmiştir. ${ }^{39}$ Yine döneme ait mahkeme kayıtlarından evlendirilen kişinin yakın velisinin rızası olmaksızın uzak velinin kıydığı nikâhın geçersiz olduğu, bu durumda nikâh akdinin fâsit kabul edilerek hâkim tarafından bozdurulabildiği anlaşılmaktadır. Nitekim bir molla tarafindan feshettirilen böyle bir nikâh akdine rastlanmıştır. ${ }^{40}$ Haddizatında bunun mollalara mahsus bir yetki olmayıp genel bir hukuki kaide olduğu belirtilmelidir. ${ }^{41}$

Mezkûr tereke kayıtları, mollaların cariye edinebildiklerini de göstermektedir. Ancak anlaşıldığı kadarıyla bu uygulama, mollalar arasında oldukça nadirdir. Zira ilgili sicillerde çok sayıda köle ve cariyeye rastlanmakla birlikte 98 tereke kaydının sadece ikisinde cariyenin yer aldığı ortaya çıkmıştır. Tereke kayıtlarının haricindeki ilgili sicil kayıtlarında da cariye veya köleye sahip olduklarına dair herhangi bir bilgiye rastlanmamıştır. $\mathrm{Bu}$ da mollaların kölelik uygulamasına karşı genel yaklaşımlarını göstermesi bakımından oldukça önemli bir görünümdür. İlgili kadı sicillerine köle ve cariyelerin alım satımı gibi birçok ilişki yansımış olmasına rağmen maddi imkânı yerinde olan birçok mollanın köle veya cariye edinmemiş olması, genel itibariyle bu uygulamaya sıcak bakmadıklarına yönelik önemli bir göstergedir. Bu sonuç, İslam ve kölelik araştırmaları açısından dikkate değer bir bulgudur.

Tereke kayıtlarında 89 mollanın toplam 170 çocuğunun olduğu tespit edilmiştir. 23 ailenin hiç çocuğu olmadığından genel ortalama 1.9 olarak ortaya çıkmıştır. Dolayısıyla ilgili dönemde molla ailelerindeki çocuk sayısının genel itibariyle düşük olduğu anlaşılmaktadır. Ancak bunun molla ailelerine mahsus bir durum olduğunu ifade etmek zordur. Zira böyle bir yargıda bulunabilmek için daha geniş çaplı bir araştırma yapılarak genel ortalama içerisindeki molla ailelerinin durumunu tespit etmek gerekmektedir. Bunun yanı sıra sicillerde kaydı bulunan terekelerin ilgili döneme ait tüm tereke kayıtlarını yansıtmadığı da göz önünde bulundurulmalıdır.

İlgili dönemde mollaların yok denecek kadar az boşanma gerçekleştirdikleri anlaşılmaktadır. Zira döneme ait sicillerde sadece altı adet boşanma ve boşanmayla ilgili kayda rastlanmıştır. Elbette ilgili dönemde boşanma işlemlerinin mahkeme huzurunda yapılma veya mahkemece kayda geçirilme gibi bir zorunluluğu yoktur. Dolayısıyla tam olarak ne kadar boşanmanın meydana geldiğini tespit edebilmek mümkün değildir. Ancak Osmanlı toplumunda, karı koca arasında belli bir anlaşma içerdiğinden dolayı

38 Başlık uygulaması hakkında geniş bilgi için bk. Ahmet Akgündüz, "Başlık", Türkiye Diyanet Vakfı İslâm Ansiklopedisi (İstanbul: TDV Yayınları, 1992), 5: 131-133.

39 DŞS, 3712, 58b-1.

40 DŞS, 3803, 10b-4.

41 M. Âkif Aydın, İslam-Osmanlı Aile Hukuku, (İstanbul: Marmara Üni. İlahiyat Fak. Vakfı Yayınları, 1985), 26. 
bilhassa muhâlea ${ }^{42}$ yoluyla meydana gelen boşanma işlemlerinin kayıt altına aldırılması hususunda hassasiyet gösterildiği bilinmektedir. ${ }^{43}$ Nitekim incelenen belgelerde rastlanan mezkûr boşanma vakalarının tamamına yakınının muhâlea akdine dair olması da bunun bir göstergesidir. Bunların haricinde doğrudan veya dolaylı olarak ilgili belgelere boşanmış herhangi bir molla hanımının yansımamış olması da dikkat çekicidir. Ayrıca karı koca arasında yaşanması muhtemel olan herhangi bir geçimsizlik problemine de rastlanmamıştır. Dolayısıyla mezkûr boşanma vaka sayısının bu denli düşük olması, aile kurumunun devamlılığı noktasında molla ailelerinin, toplumun geneline nispetle daha sağlıklı olduğunu ihsas etmektedir. ${ }^{44}$

Döneme ait sicillere yansıyan mollaların tamamına yakınının, şehir merkezi olan Amid'in mahallelerinde sakin oldukları gözlenmiştir. Nadiren de olsa köylerde ikamet eden mollalar da belgelere yansımıştır, fakat bunlar oldukça azdır. Bu durum mollaların genel itibariyle şehir merkezinde sakin olduklarına işaret etmektedir. Ancak kırsal kesim sakinlerinin muhtelif sebeplerle şehir merkezindeki insanlar kadar mahkeme sicillerine yansımamış olma ihtimalini göz önünde bulundurmakta fayda vardır.

\section{Mollaların Toplumsal İliş̧kileri}

Döneme ait kadı sicillerinde yer alan dava kayıtları ve diğer belgeler, mollaların reayadan farklı olarak özel bir hukuki statüye sahip olmadıklarını açık bir biçimde göstermektedir. Bir başka ifadeyle ilgili belgelerde molla unvanına sahip kişilere yönelik özel bir hukuki uygulamaya rastlanmamıştır. Ancak kadı sicillerine yansıyan bilhassa hukuki işlemler ve dava kayıtları, mollaların toplumla sıkı bir irtibat halinde olduklarını, halk nezdinde saygın ve güvenilir bir konumlarının bulunduğunu, sosyal sorumluluk bağlamında önemli görevler üstlendiklerini ortaya koymuştur. Nitekim araştırma sürecinde bu çıkarımı destekleyecek birçok bulguya ulaşılmıştır. Şimdi bu bulgulara kisaca temas edilecektir.

$\mathrm{Bu}$ çerçevedeki en belirgin görünümler mollaların, halk arasında meydana gelen davalarda ve hukuki işlemlerdeki rollerinde ortaya çıkmaktadır. Mollalar, döneme ait dava kayıtlarında ve alım satım gibi hukuki işlemlerde tarafları temsil eden vekiller, bu vekâletlerin sıhhatine ve doğruluğuna tanıklık eden kişiler, davaların ispatını sağlayan şahitler ve dava duruşmasına tanıklık eden şühûdü'l-hâl olarak oldukça yoğun ve belirgin biçimde belgelerde yer almışlardır. Toplumun, hukuki işlemlerde ve davalarda kendilerini mahkeme huzurunda temsil edecek kişiler olarak bilhassa mollaları tercih etmeleri, onlara duyulan güvenin önemli bir göstergesidir. Aynı zamanda rutin bir uygulama olan vekâlet işleminin sıhhat ve doğruluğuna tanıklık eden kişiler olarak da sıklıkla mahkemede yer almışlardır. ${ }^{45}$ Yine birçok davanın ispatlanma sürecinde

${ }^{42}$ Fahrettin Atar, "Muhâlea", Türkiye Diyanet Vakfi İslâm Ansiklopedisi (İstanbul: TDV Yayınları, 2005), 30: 399.

43 Aydın, İslam-Osmanlı Aile Hukuku, 114 vd.; Madeline C. Zilfi, "Geçinemiyoruz: 18. Yüzyılda Kadınlar ve Hul”, Modernleşmenin Eşiğinde Osmanlı Kadınlarl, ed. Madeline C. Zilfi (İstanbul: Tarih Vakfı Yurt Yayınları, 2014) 269; Ümit Güler, "XVII. Yüzyıl Kıbrıs Kadı Sicilleri Işı̆ıında Osmanlı Kıbrısı'nda "Evliliğin Sona Ermesi”", Marmara Üniversitesi Ilâhiyat Fakültesi Dergisi 52/52 (Haziran 2017): 75.

${ }^{44}$ Abdurrahman Kurt, Bursa Sicillerine Göre Osmanl Ailesi (1839-1876), (Bursa: Uludağ Üniversitesi Basımevi, 1998), 57-59; Zilfi, "Geçinemiyoruz: 18. Yüzyılda Kadınlar ve Hul”, 268; Güler, "XVII. Yüzyıl Kıbrıs Kadı Sicilleri Işı̆̆ında Osmanlı Kıbrısı'nda "Evliliğin Sona Ermesi””, 87.

45 Örnek olarak bk. “...Medîne-i Âmid mahallâtından Derviş Hüseyin mahallesinde sâkine Zeliha bt. Mehmed Emin nâm hâtûn tarafindan husûs-1 âti'l-beyânda vekîli olduğu zât-1 mezbûreyi ma'rifet-i 
şahitlikte bulunmaları ve "udûl-i ahrâr-1 ricâl-i müslimîn"46 olarak tanımlanmaları, onların güvenilirliklerine işaret etmektedir. Bunlardan daha dikkat çekici olanı, döneme ait kadı sicillerinde mollaların en fazla gözlendiği yerlerin, şühûdü'l-hâl üyeliği olmasıdır. Molla unvanına sahip kişilerin şühûdü'l-hâl üyesi olarak belgelerde yoğun biçimde yer almaları oldukça önemli bir bulgudur. Zira şühûdü'l-hâl (hâl şahitleri), mahkemelerde adil karar verildiğine ve aleniyete şahitlik eden kişilerdir. En az iki kişiden oluşan şühûdü'l-hâl, davayı dinler, davanın usulüne uygun biçimde görüldüğüne tanıklık eder ve gerekli hallerde hâkim tarafından görüşlerine başvurulabilirdi. Bu kimselerin hazır bulunmadığı veya hükmü imzalamadığı bir dava muteber sayılmazdı. ${ }^{47}$ Böylesine önemli bir görevi ifa eden kişilerin de genelde toplumun ileri gelen, saygın üyelerinden oluştuğu belirtilmektedir. ${ }^{48}$

Mollaların, toplum içerisinde ihtiyaç halinde olan yetim, dul veya mağdur kişilerin haklarını teslim alabilmeleri ve mağduriyetlerinin giderilmesi için gerekli hallerde mahkemeye müracaat ettikleri de gözlenmiştir. ${ }^{49}$

Döneme ait kadı sicilleri mollaların toplumun güven ve saygısına uygun hareket edip etmediklerine veya bu güven ve saygıya muvafik bir yaşam tarzına sahip olup olmadıklarına dair önemli veriler ortaya koymaktadır. Bilhassa asayiş vakaları, bu hususa 1 şık tutması bakımından oldukça dikkat çekicidir. Önemine binaen bu husus, ileride müstakil olarak ele alınacaktır. Ancak bu noktada şu kadarı ifade edilebilir ki incelenen dönemin zaman aralığının genişliği göz önünde tutulduğunda, mollaların işledikleri suçların yok denecek kadar az olduğu ortaya çıkmaktadır. Şüphesiz bu sonuç, mollaların genel ahlaki durumlarına ve yaşam tarzlarına dair önemli bir görünümdür.

İlgili belgeler kimi mollaların isimlerinin mahalle ve köylere verildiğini de göstermektedir. Sicillerde altı mahalle ve yine altı köy isminin mollalara ait olduğu saptanmıştır. İsimler şöyledir:

Molla Bekir Mahallesi, ${ }^{50}$ Molla Alican Mahallesi, ${ }^{51}$ Molla Bahaeddin Mahallesi, ${ }^{52}$ Molla Cenan Mahallesi, ${ }^{53}$ Molla Hayyan Mahallesi, ${ }^{54}$ Molla Alihan Mahallesi; ${ }^{55}$ Karyei Molla Polad, ${ }^{56}$ Karye-i Molla Cabir, Karye-i Molla Hamiş, Karye-i Molla Ali, ${ }^{57}$

şer 'ile ârifân Molla Mahmud b. İbrahim ve Mustafa b. Rüstem şahâdetleriyle şer'an nâib olan Tütüncü Abdullah Çelebi...” DŞS, 3789, 9a-2.

${ }^{46} \mathrm{Bu}$ tanımlama mollalara özgü olmayıp dava sürecine müdahil olan tüm şahitlerde aranan genel bir niteliktir.

47 Ekrem Buğra Ekinci, Osmanlı Hukuku, (İstanbul: Arı Sanat Yay., 2012), 376; Ronald C. Jennings, Studies on Ottoman Social History in the Sixteenth and Seventeenth Centuries: Women, Zimmis and Sharia Courts in Kayseri, Cyprus and Trabzon, (İstanbul: The Isis Press, 1999), 257-258.

48 Jennings, Studies on Ottoman Social History in the Sixteenth and Seventeenth Centuries: Women, Zimmis and Sharia Courts in Kayseri, Cyprus and Trabzon, s. 257-258; Mustafa Akdağ, Türkiye'nin İktisadî ve İçtimâ̂ Tarihi, (İstanbul: Yapı Kredi Yayınları, 2010), 437; Hülya Taş, “Osmanlı Kadı Mahkemesindeki "Şühûdü'l-Hâl” Nasıl Değerlendirilebilir?”, bilig 44 (Kış, 2008): 34.

49 Örnek için bk. DŞS, 3828, 1a-1.

50 DŞS, 3789, 30b-2.

51 DŞS, 3789, 2b-1.

52 DŞS, 3789, 2b-2; Mahalle-i Molla Bahaeddin-i müslim, Mahalle-i Molla Bahaeddin-i zimmî bk. DŞS, 3709, 22a-1.

53 DŞS, 3789, 19b-1.

54 DŞS, 3709, 22a-1.

55 DŞS, 3712, 27a-3.

56 DŞS, 3828, 4b-1. 
Karye-i Molla Cücük ${ }^{58}$ ve Karye-i Molla Aliler. ${ }^{59}$ Mezkûr köy ve mahallelere mollaların isimlerinin verilmesi onlara atfedilen saygı ve değerin önemli bir göstergesidir.

\section{Mollaların Kültürel ve İlmi Durumları}

Daha önce de ifade edildiği gibi ilgili belgeler molla unvanının, dinî işlerle veya eğitimle ilgilenip ilgilenmemesine bakılmaksızın umumi olarak medrese tahsili görmüş kişiler için kullanıldığını ortaya koymaktadır. Dolayısıyla bu dönemde esnaflık yapan mollalar olduğu gibi bahçıvanlıkla uğraşan veya imamlık, müezzinlik görevi ifa eden mollalar da vardır. Mollaların meslekleriyle ilgili olan bu konuya bir sonraki başlıkta temas edilecektir. Bu başlık altında ele alınmak istenen mevzu, mollaların ilmi ve kültürel durumlarına dair elde edilen bazı bulgulardır. Mahkeme sicilleri yapısı gereği bu hususta doğrudan pek fazla bilgi ihtiva etmese de belgelerden dolaylı olarak bazı sonuçlara ulaşmak mümkündür. Nitekim tereke kayıtları bu konuda oldukça işlevseldir. Değinildiği gibi ilgili dönemdeki mollalara ait 98 adet tereke kaydı tespit edilmiştir. Bu tereke kayıtlarında yer alan kitaplardan, bunların sayılarından ve çeşitlerinden de mollaların ilmi ve kültürel durumlarına dair bazı ipuçları elde edilebilmiştir. Ancak bu noktada şu ifade edilmelidir ki mollaların terekelerinde kitapların yer almaması, onların kitaplarla hemhal olmadıklarına veya ilmi-kültürel durumlarının zayıf olduğuna yönelik bir değerlendirme için yeterli bir argüman değildir. Zira mollaların medrese kütüphanelerinden istifade etmeleri veya vefatlarından önce kitaplarını buralara hibe etmeleri mümkündür. Nitekim Osmanlı dönemi Diyarbekir'inde kütüphanenin medreselerin çoğunda tamamlayıcı unsur olarak düşünüldüğü; medreselerin yanı sıra cami ve mescitlerde de kütüphanelerin kurulduğu ifade edilmektedir. ${ }^{60}$ Bunun yanı sıra kitabın oldukça değerli olduğu bir dönemde mollaların vefatlarından önce kitaplarını satmış veya başka kimselere bağışlamış olmaları da pek tabii mümkündür. Haddizatında bu gibi işlemlerin mahkemece tescil edilmesi gibi bir hukuki gereklilik de bulunmadığından sicillere yansımamaları olası bir durumdur.

İlgili tereke kayıtlarında yer alan Kur'an-1 Kerimler dikkate alınmayacak olursa 98 mollanın 20'sinin (\%20.4) terekesinde bir veya birden fazla kitabın yer aldığ söylenebilir. Bunların içerisinden de üç ve daha fazla kitabın yer aldığı tereke sayısı 11 (\%11.2) dir. Kitapların haricinde altı (\%6.1) mollanın terekesinde de dividin ${ }^{61}$ yer aldığ görülür. İsimleri zikredilen kitapların büyük çoğunluğu, klasik medrese müfredatına yönelik eserlerdir. Bunlar daha çok fikıh, ${ }^{62}$ tefsir, hadis, Arapça, mantık ve edebiyattan oluşur. Sahip olduğu kitap sayısı fazla olan kişilerin isimlerinin genelde yalın olarak molla olduğu, terekesinde kitap sayısı az olan veya hiç kitap bulunmayan kişilerin ise istisnai halleri olmakla birlikte- pamukçu, bahçıvan, manifaturacı, eskici gibi mesleki sıfatları da taşıdıkları dikkat çekmektedir.

57 DŞS, 3709, 25b-1.

58 DŞS, 3823, 7a-1.

59 DŞS, 3798, 5a-3.

60 Acar, "Diyarbakır Medreseleri ve Osmanlı Eğitim Sistemi İçerisindeki Yerleri”, 1: 141.

${ }^{61}$ Divit veya çoğul olarak devât, kalem koymak için uzun madenî sap1 ve ucunda hokkası bulunan âleti ifade eder. bk. Ferid Devellioğlu, "Devât", Osmanlıca-Türkçe Ansiklopedik Lûgat, (Ankara: Aydın Kitapevi, 2010), 204.

623 terekede zikrolunan fikıh kitaplarının tamamı Hanefî mezhebine aittir. Dolayısıyla bu mollaların Hanefî mezhebinden oldukları kuvvetle muhtemeldir. (bk. Ek 1). 1 tereke kaydından (bk. Ek 1. DŞS, 3707, 97b-1) ve bunun dışındaki belgelerden Şafiî mollaların da bulunduğu anlaşılmaktadır. DŞS, 3731, 27a-1. 
Daha önce değinildiği gibi bu dönemde birçok kişinin medrese tahsili gördüğü ve bu kişilerin bir kısmının tahsilden sonra daha çok esnaf ve zanaatkârlık mesleğini tercih ettikleri anlaşılmaktadır. Esnaf ve zanaatkârlık yapan bu kimselerin ilimle pek fazla iştigal etmemiş olmaları takdir edilebilir bir durumdur. Ancak terekelerinde çok sayıda kitap ve divit bulunan mollaların bulunduğu ve bunların da ilimle iştigal ettikleri anlaşılmaktadır. Bu kimselerin medrese hocası veya ulemadan olma olasılığı vardır. Ancak belgelerde buna dair herhangi bir bilgi paylaşılmış değildir. Sonuç olarak ilgili siciller, oldukça geniş bir yelpazede mesleki tercihleri olan mollaların, konumlarına ve şartlarına bağlı olarak ilmi ve kültürel düzeylerinin değişkenlik arz ettiğini ihsas etmekle birlikte genel itibariyle bu düzeylerinin yüksek olduğuna işaret etmektedir.

\section{Mollaların İktisadi İlişkileri}

Kadı sicillerine yansıyan toplumsal ilişkilerin oransal açıdan çoğunluğunu genellikle alım satım veya alacak verecek meseleleri gibi iktisadi ilişkiler teşkil etmektedir. Dolayısıyla ilgili siciller mollaların iktisadi ilişkilerine dair oldukça kıymetli bilgiler sunmuştur. İlk olarak mollaların alış veriş ilişkilerine bakılacak olursa mollaların önemli bir kısmının esnaf ve zanaatkâr olması sebebiyle ticari olarak toplumun hemen her kesimiyle temas halinde oldukları ve bu çerçevede belgelere sıklıkla yansıdıkları söylenebilir. Ticarete konu olan menkul veya gayrimenkul eşya açısından ilişkilerin büyük çoğunluğunun menkul kapsamda gerçekleştiği gözlenmiştir. Bunlar hibe, karz (ödünç) ve daha ziyade alış verişten kaynaklı borç gibi sebeplerle meydana gelmiştir. Gayrimenkulde ise neredeyse tamamen ev alım satımı söz konusu olmuştur. Bu alım satım işlemlerinin hangi yönde gerçekleştiğine bakıldığında doğrudan ev alım satımına dair tespit edilen kayıt sayısının 23 olduğu ve bunların 13'ünün mollalar tarafından satın alma, 10'unun da satım yapma şeklinde vuku bulduğu görülür. Dolayısıyla ev alım satımının birbirine oldukça yakın oranda gerçekleştiği, hâkim bir temayülün bulunmadığ 1 söylenebilir. Alım satım rakamının bu denli düşük olması, vaki olan durumu yansıtmamaktadır. Zira mollaların ev alım satım işlemlerinin bu rakamdan daha fazla olduğu, belgelere dolaylı olarak yansıyan meselelerden anlaşılmaktadır. $\mathrm{Bu}$ da alım satım tescilinin herhangi bir resmi zorunluluğunun bulunmaması sebebiyle tüm işlemlerin kayıt altına alınmadığını göstermektedir.

Döneme ait kadı sicillerinden mollaların mesleki hayatlarına dair de kıymetli bilgiler elde edilmiştir. Zira mezkûr belgelerde molla unvanını taşıyan kimselerin isimlerinin önünde varsa mesleki unvanları da zikredilmiştir. Bu unvanlardan mollaların hangi mesleklere sahip olduklarına dair bilgilere ulaşılabilmektedir. Tereke kayıtlarına göre mollaların \%31.6'sının ilmi anlam ifade eden molla unvanlarıyla beraber icra ettikleri mesleki unvanlarının da olduğu gözlenmiştir. Bu mesleki unvanlardan mollaların muhtelif birçok mesleği icra ettikleri anlaşılmıştır. İlgili dönemde mollalar, kuyumcular şeyhliğinden ${ }^{63}$ hamamcılığa, mektep hocalığından medrese kapıcılığına kadar muhtelif düzeylerde birçok farklı mesleğe sahip olabilmişlerdir. Bunun yanı sıra mollaların özellikle esnaf ve zanaatkârlar arasında oldukça yaygın olduğu; berber, attar, pamukçu, sarraf, kasap, tütüncü, barutçu, kılıççı veya sabuncu gibi altmıştan fazla farklı mesleği icra ettikleri tespit edilmiştir. ${ }^{64}$

63 Osmanlı'da esnaf şeyhleri, esnafın büyüğü anlamına gelirdi; esnafın şikâyetleriyle ve devletle esnaf arasındaki işlerle meşgul olurdu. bk. Pakalın, Osmanlı Tarih Deyimleri ve Terimleri Sözlüğü, 1: 557. Geniş bilgi için bk. Mehmet Demirtaş, Osmanlı Esnafinda Suç ve Ceza, (Ankara: Birleşik Yay., 2010), 29.

64 bk. Ek. 2. 
Mollaların din hizmetleri dışında özel olarak belli bir mesleği icra edip etmediklerine dair yaptığımız incelemede genel anlamda esnaf ve zanaatkârlık alanında yoğunlaştıkları anlaşılmaktadır. Mesleki olarak da geniş bir yelpazede ve oldukça farklı alanlarda mesleklere sahip olabilmişlerdir. Ancak siciller, mollaların genellikle şehir hayatı içerisinde cari olan meslekleri icra ettiklerini, tarım ve hayvancılıkla uğraşanlarının oldukça az olduğunu göstermiştir. Mollalar medrese tahsili gördüklerinden belli bir kültür ve bilgi birikimine sahip olmuşlar ve muhtemelen bu donanımları onların daha çok şehirde yaşamalarına ve toplum içerisinde orta sınıf tabir edilebilecek meslekleri icra etmelerine olanak sağlamıştır. Nitekim imamlık, müezzinlik, vakıf mütevelliliği, beytülmal eminliği, muhzırlık, tercümanlık, kâtiplik gibi dinî, adli veya idari görevler üstlenmeleri bu niteliklerinin bir göstergesidir.

Döneme ait sicillerin ortaya koyduğu dikkat çekici bir başka görünüm de mollaların alacak verecek meselelerinin son derece düşük olmasıdır. Zira mahkeme defterlerine bu kapsamda sadece altı ihtilaf yansımıştır. Bu ihtilafların birinde alacaklı ve borçlu kişileri, yani tarafları mollalar teşkil etmişken, ${ }^{65}$ diğerlerinde mollalar borçlu konumdadırlar. ${ }^{66}$ Borçlar genelde ticari sebeplerle meydana gelmiş, kimi zaman da karzdan kaynaklanmıştır. Ancak her iki durumda da mollalar genellikle borçlarını ikrar etmişlerdir. Fakat ödeme tarihi, borcun miktarı veya borcun sabit olup olmadığ 1 gibi sebeplerden kaynaklanan bazı ihtilaflı hallerde meselelerin mahkemeye taşındığı olmuştur.

Mezkûr alacak verecek ihtilaflarında ilgili mollaların esnaf, tacir veya zanaatkâr olduğuna dair herhangi bir bilgiye rastlanmamıştır. Bu durum oldukça dikkat çekicidir. Zira daha önce de ifade edildiği gibi bu dönemde mollaların önemli bir kısmı esnaf ve zanaatkârdır. Bunun yanı sıra esnaf ve zanaatkâr mollalar, tereke kayıtlarında alacaklı veya borçlu olarak birçok defa zikrolunmuşlardır. Dolayısıyla mollaların iktisadi hayat içerisinde aktif oldukları açıtır. Hâl böyleyken bu kimselerin alacak verecek meselelerinin yok denecek kadar az olması, sağlıklı ve dürüst bir ticari hayata sahip olduklarına yönelik önemli bir göstergedir.

Döneme ait belgeler, mollaların ticari hayatta birçok defa aldatıldıklarını ortaya koymaktadır. Zira bu dönemde kendilerine çalıntı veya gasp edilmiş malların satılarak mağdur edildiklerini gösteren birçok örneğe rastlanmıştır. Mollaların taraf olduğu bu tür 12 vaka kaydı tespit edilmiştir. ${ }^{67} \mathrm{Bu}$ davalarda mollaların ellerindeki merkep, beygir, tay, kısrak ve öküz gibi hayvanların esas sahibi olduklarını iddia eden kişiler, mahkemeye müracaat etmiş ve mallarının kendilerine iade edilmesini talep etmişlerdir. Davacıların ifadelerine göre beş vakada malların kaybolduğu, iki vakada çalındığı ve yine iki vakada gasp edildiği anlaşılmaktadır. Diğer vakalarda bu hususa dair bilgi verilmemiştir. 12 davanın sekizinde davacının iddiasını ispatladığı anlaşılmakla beraber diğer kayıtlarda dava süreci tamamlanmadığından sonuçlar netleşmemiştir.

İddiaların hiçbirinde mollalar hırsızlıkla veya herhangi bir suçla itham edilmemişlerdir. Haddizatında mollaların savunmasından da anlaşılan odur ki çalıntı veya haksızca el konulan mezkûr hayvanlar mollalara satılmıştır. Daha sonra hayvanların asıl sahipleri mallarını tespit ettiklerinde taraflar arasında ihtilaf çıkmıştır. Böylesi durumlarda

65 DȘS, 3798, 7b-1.

${ }^{66}$ DŞS, 3798, 18a-3; DŞS, 3767, 3a-2; DŞS, 3791, 5a-4; DŞS, 3702, 2b-5; DŞS, 3702, $26 a-4$.

67 DŞS, 3798, 2a-2; DŞS, 3798, 13a-5; DŞS, 3767, 3a-2; DŞS, 3767, 13a-2; DŞS, 3767, 13b-3; DŞS, 3767, 29a-1; DŞS, 3767, 9b-3; DŞS, 3803, 13a-1; DŞS, 3803, 13b-5; DŞS, 3803, 35b-5; DŞS, 3803, 35b-6; DŞS, 3702, 19a-2. 
mollaların dava konusu hayvanları kimden satın almışlarsa onlar aleyhine ayrı bir dava açabildikleri ve bu süreçte takip edilmesi gereken hukuki prosedür belgelere yansımıştır. ${ }^{68}$ Ancak bu yönde açılan sadece bir davaya rastlandığından bu kimselere genelde ulaşılamadığı muhtemeldir.

Mollaların tereke kayıtları da onların iktisadi durumlarına dair kıymetli malumat sunabilmiştir. $\mathrm{Bu}$ kayitlarda 27.558 .5 kuruş $^{69}$ veya 14.438 kuruş 30 para $^{70}$ gibi miktarlarla oldukça zengin olduğu anlaşılan mollalara rastlanmakla beraber borçları miraslarından fazla olan (guremâ) ${ }^{71}$ mollalar da bulunmaktadır. Ancak "guremâ" durumundaki sekiz ve aşırı zengin iki molla kapsam dışı bırakılırsa yaklaşık \%90 gibi bir oranla büyük çoğunluğun orta halli bir ekonomik güce sahip olduğu söylenebilir.

Döneme ait belgeler, mollaların gayrimüslimlerle olan ilişkilerine de 1şık tutmaktadır. Özellikle tereke kayıtlarında mollaların ve gayrimüslimlerin birbirleri üzerindeki alacak verecek hesaplarından bahsedilmesi önemlidir. ${ }^{72}$ Zira bu durum, gruplar arasındaki sosyal ve iktisadi ilişkilerin varlığına işaret etmektedir. İpekçilik yapan bir mollanın kendisi gibi ipekçi olan bir Yahudi'nin dükkânına emanet mal bırakması gibi mesleki ilişkilere rastlanmıştır. ${ }^{73}$ Ticari konularda yaşanan ihtilaf hallerinde vardıkları sulh akdini mahkeme tarafindan kayıt altına aldırdıklarr ${ }^{74}$ ve yine borç tahsilatı talebiyle mahkemeye müracaat edildiği de olmuştur. ${ }^{75}$ Tüm bunlar, mollaların gayrimüslimlerle temas ve iletişim halinde olduklarını göstermesi bakımından dikkate değerdir. Daha da önemlisi, mezkûr zümrelerin bir diğerine karşı herhangi bir hak tecavüzüne veya baskısına yönelik en küçük bir emareye dahi rastlanmamıştır. Gayrimüslimler, vuku bulan bir anlaşmazlık durumunda ahalinin seçkin kimselerinden olan mollaları dava edebilmiş ve mahkeme huzuruna çıkarıp yargılatabilmişlerdir. Belgelere yansıdığ kadarıyla bu süreçte herhangi bir özel muamele veya ayrıcalık söz konusu olmamıştır.

68 "Yeniceli Molla Hüseyin Metinanlı zir karyesinden Diro muvâcehesinde üzerine bundan akdem merkūmdan yüz elli kuruşa bir re's öküz iştirâ eyledim dokuz mâh indimde kaldıkdan sonra Nuh Bey'in hizmetkârı Asâf benim malımdır ve yedimden zâyi‘ olmuş deyu beni huzûr-1 şer'e şekva mâlı olup yedinde zâyi` oldugunu şâhidin ile huzûr-1 şer'de isbât ve ahz etmekle el haletü hazihi merkūm Diro baliğim olmağla meblağ-1 mezbûrun tahsîli matlûbumdur deyu da'va merkūm cevâbında Asaf'ın mülk-i müşteram deyu zabt etmiş ise de öküz-i merkūm benim netacen mülküm olup sana füruht etmişim deyu def'a-i tasaddî ve semen-i bakīsi edâdan imtinâ' edip bu cihetle tarafeyn dahi fetvâya mürâca'at olundu merkūm Molla Hüseyin Diro'dan Öküzün semenini ahz edebilir mi yoksa netâcen mülkü olduğunu sâbit eder ise yine Asâf'a rücû‘ eder mûceb-i şer'isi zeyli kitâbe tahrîr oluna

El-haletü hazihi Molla Hüseyin Diro'dan öküzün semenini ahz eder Diro dahi ba'dehu Asâf'a dest-i res oldukda Asaf'ın muvâcehesinde mezkûr öküz netâcen mülkü olduğunu huzûr-1 şer'de lede'l-isbât öküzünü zabt eder.” DŞS, 3791, 9b-3.

${ }^{69} \mathrm{Bu}$ miktarın alım gücüne dair bir fikir sahibi olmak için ilgili zamandaki küçük ve büyükbaş hayvan fiyatlarıyla mukayesede bulunulabilir. Aynı yıla ait bir tereke kaydında keçinin 20 kuruş, ineğin ise 50 kuruş olduğu kaydedilmiştir. Hayvanın niteliğine göre bu bedellerin az bir miktar değişmesi mümkün olsa da mezkûr terekedeki 27.558.5 kuruşun, yaklaşık 1.378 adet keçi ve 551 adet ineğe tekabül ettiği söylenebilir. bk. DŞS, 3747, 48b-1.

${ }^{70} \mathrm{Bu}$ kaydın ait olduğu yılda bir koyun bedelinin 19 kuruş olduğu zikredilmektedir. Dolayısıyla mezkûr meblağ 760 adet koyuna tekabül etmektedir. DŞS, 3768, 15a-1.

71 Guremâ taksimi, tamamı borçları karşılamayan terekenin alacaklılara hakları oranında taksim edilmesidir. bk. Mehmet Erdoğan, Flkıh ve Hukuk Terimleri Sözlüğü, (İstanbul: Ensar Neşriyat, 2005), 160.

72 DŞS, 3773, 35b-2; DŞS, 3785, 17a-1.

${ }^{73}$ DŞS, 3791, 7b-4.

74 DŞS, 3791, 8a-1.

75 DŞS, 3803, 16a-1; DŞS, 3803, 22a-2. 


\section{Mollaların Suç İlişkileri}

İncelenen dönem zaman olarak geniş ve belge olarak da zengindir. Buna rağmen mollalara dair suç hadiselerinin son derece az olduğu ortaya çıkmıştır. İlgili dönemde mollaların bazı cinayet davalarında adları geçmektedir. Ancak cinayet işlediklerini ispatlı biçimde gösteren herhangi bir bilgi veya bulguya ulaşılmamıştır. Bir vakada aralarında bir mollanın da bulunduğu bir grup tarafından cinayetin işlendiği iddia edilmiş ve bu gruptan bir kişinin suçu ikrar ettiği ispatlanmıştır. 30 Zilkade 1159 (14 Aralık 1746) tarihli belgeye göre Hani kazasının Şeyh Ömeran köyünden maktul Musa bin Süleyman'ın yakınları mahkemeye müracaat ederek, belge tarihinden bir ay önce Musa b. Ahmed, Ali b. Eyüb, Hasan b. Mustafa, Molla Ali b. Ahmed'in hep birlikte maktulü gece vakti boğazlayarak öldürdüklerini iddia etmiş ve mezkûr zanlılardan Musa b. Ahmed'in Dağ Kapısı haricinde Buzhane civarında arkadaşlarına "Musa'yı katl eyledim mâlını sepetden çıkarmağa komadınız" dediğini şahitler vasıtasıyla ispatlayarak diyet talep etmiş̧ir. Bu vakada adı geçen Molla, olay yerinde bulunmuş olsa da ifadelerden cinayeti işleyen kişinin kendisi olmadığı anlaşılmaktadır. Aynı zamanda olayda bir rolünün olup olmadığı da aydınlatılmış değildir. Nitekim belgede de dava sonucu yer almamıştır. ${ }^{76}$

1 Muharrem 1152 (10 Nisan 1739) tarihli bir diğer kayıtta ise Diyarbekir'in Siverek kazasından maktul Ali b. Abdullah'n yakınları, Ahmed Ağa ve Monla Mustafa ve Monla İsmail ve Abbas b. Ali ve Bayrakdar Ahmed ve Monla Nebi'nin maktul ile kavga ettikleri esnada kurşun ile kendisini vurduklarını ve maktulün bu sebeple vefat ettiğini iddia etmişlerdir. Adı geçen kişilerin suçu inkâr etmesiyle araya arabulucular (muslihûn) girmiş ve tarafları 825 kuruş üzerine sulha razı etmişlerdir. Mezkûr belge, bu sulh akdinin kayda geçirilmesine dairdir. Dolayısıyla bu vakada da cinayetin failleri net olmadığı gibi mollaların cinayet suçunu işledikleri de ispatlanmış değildir. ${ }^{77}$ Ancak bir şekilde olayın içerisinde yer aldıkları anlaşılmaktadır.

Evâsit-1 Safer 1239 (17-26 Ekim 1823) tarihli bir belgede cinayet ithamı olmasa da ölüme sebebiyet verdiği iddiasıyla Debbâğ ${ }^{78}$ Molla Mehmed ile maktul Corcoroğlu Mustafa b. Hacı Mehmed'in varisleri arasında 500 kuruş üzerine sulh akdinin gerçekleştirildiği kayıt altına alınmıştır. Belgede Debbâğ Molla Mehmed'in maktulün ölümüne sebebiyet vermekle itham edildiği anlaşılmaktadır. ${ }^{79}$ Mezkûr mollanın sulh amacıyla 500 kuruşluk ciddi bir meblağı ödemesi sebebiyle olayda bir sorumluluğunun olduğu muhtemeldir. Ancak ispatlı bir suçunun olmadığı da açıktır. ${ }^{80}$

Döneme ait mahkeme sicillerine göre mollaların cinayet vakalarıla olan irtibatı yukarıda zikredilen vakalarla sınırlıdır. İlgili belgelerden mollaların ispatlanmış herhangi bir cinayet suçlarının olmadığı anlaşılmaktadır. Bunların yanı sıra incelenen dönemde maktul konumunda olan sadece bir mollaya rastlanmıştır. Bu vaka da dolaylı

76 DŞS, 3712, 60b-1.

77 DŞS, 3754, 97a-2.

78 Debbâğ, tabak, sepici, deri terbiye eden kimse anlamına gelir. bk. Devellioğlu, "Debbâğ", Osmanlıca-Türkçe Ansiklopedik Lûgat, 192.

79 “....Mevrûsumuz müteveffâ-yı merkûmu bundan akdem Diyarbekir Vâlîsi Mehmed Paşa'ya sevk edip sevki sebebiyle katl olunduğundan dem u diyetini da'vâ sadedinde olduklarımızdan müslimûn ve muslihûn tavassutuyla beş yüz guruşa sulh olunup bedel-i sulhu meclis-i sulhda tamâmen ve kâmilen ahz u kabz eyledik...” bkz. DŞS, 3745, 13b-1.

80 DŞS, 3745, 13b-1. 
olarak belgeye yansımış olup cinayet hakkında bilgi verilmemiştir. ${ }^{81}$ Binaenaleyh mahkeme kayıtları, mollaların neredeyse hiçbir cinayete maruz kalmadıklarına işaret etmektedir.

Mollaların ilgili dönem sicillerine yansıyan suç vakalarıyla irtibatı mezkûr vakalardan ibarettir. Dolayısıyla bu dönemde mollaların hangi mesleği icra ederse etsin genel itibariyle son derece güvenilir ve zararsız oldukları ortaya çıkmaktadır. Onlara karşı işlenen suçların son derece az olmasında da bu niteliklerinin rolü olsa gerektir.

\section{Sonuç}

Osmanlı'daki mollalık kurumu üzerine henüz yeterli çalışmalar gerçekleştirilmediğinden konu aydınlığa kavuşturulmuş değildir. Bu mütevazı çalışma ile bilhassa sosyal tarih araştırmaları için oldukça kıymetli olan şer'iyye sicilleri temelinde ve Diyarbekir örneğinde mollaların sosyal hayatına 1 şık tutulmaya çalışılmıştır.

İlgili belgeler molla (monla) unvanının, belirli bir mesleki zümreyi ifade etmekten ziyade medrese mezunları için kullanılan ilmi bir unvan olduğunu ortaya koymuştur. Tereke kayıtlarına göre bu kişilerin \%31.6'sı mollalık unvanıyla beraber mesleki unvan da taşımışlardır. Buna göre bu dönemde mollaların önemli bir kısmı esnaf ve zanaatkâr olarak dinî hizmetlerin dişında faaliyet göstermişlerdir; imamlık, müezzinlik gibi dinî hizmetlerle birlikte genel olarak altmıştan fazla mesleği icra ettikleri ortaya çıkmıştır.

Mollaların ekonomik açıdan orta düzey ve az da olsa alt düzey ailelerden geldikleri gözlenmiştir. Mollaların kendilerinin de büyük çoğunluğunun orta halli olarak tabir edilebilecek bir ekonomik güce sahip oldukları söylenebilir. Mollalar, gayrimüslimler de dâhil olmak üzere toplumun tüm kesimleriyle sosyal ve iktisadi ilişkiler kurmuşlardır.

Tereke kayıtlarına göre mollaların \%90'ından fazlası evlidir ve evli olanların \%87.6's1 tek eşlidir. Bu sonuç mollaların ilgili dönem Diyarbekir'indeki tek eşlilik ortalamasının üstünde olup mollaların yaklaşık \%10'luk bir oranla daha az poligami (çok eşlilik) yaptığını ortaya koymuştur. İlgili dönemde kimi Müslüman erkeklerin gayrimüslim kadınlarla evlendikleri gözlenmiş olmakla birlikte mollaların tamamının herhangi bir zümreyle (molla, seyyid, şerif vs.) sınırlı olmayan Müslüman kadınlarla evlendikleri ortaya çıkmıştır. Osmanlı toplumunda boşanmaların az olduğu bilinmektedir. Ancak mollaların yok denecek kadar az sayıda boşanma gerçekleştirmiş oldukları da dikkat çeken bir olgudur.

İlgili dönemde reaya arasında çok sayıda köle ve cariyenin kullanıldığı gözlenmiştir. Ancak -iki molla hariç- zengin addedilebilecek birçok mollanın köle veya cariye edinmeyi tercih etmedikleri ortaya çıkmıştır. Bu sonuç mollaların kölelik uygulamasına sıcak bakmadıklarına yönelik önemli bir göstergedir.

Bilhassa mahkemede gerçekleştirilen hukuki işlemlerdeki konumları, bu dönemde mollaların toplumla sıkı bir irtibat halinde olduklarını, sosyal sorumluluk bilinçlerinin yüksek olduğunu ve sosyal sorumluluk bağlamında önemli görevler üstlendikleri ortaya koymuştur.

${ }^{81}$ DŞS, 3789, 38b-2. 
Mollaların bu dönemde neredeyse hiçbir suç hadisesine karışmamış olmaları dikkat çekicidir. Özellikle çok sayıda mollanın esnaf ve zanaatkârlıkla iştigal etmesine rağmen sonucun bu şekilde ortaya çıkması, Osmanlı'daki din eğitiminin birey ve toplum kalitesini yükseltmeye yönelik başarısını yansıtmaktadır. Zira belgelerle ortaya konduğu üzere, onlar toplum hayatını ıslah edici ve geliştirici bir rol oynamışlardır. Bunun yanı sıra oldukça geniş bir yelpazede mesleki tercihleri olan mollaların konumlarına ve şartlarına bağlı olarak sosyal statülerinin tabii olarak değişkenlik arz ettiği anlaşılmıştır. Ancak esnaf ve zanaatkârlar da dâhil olmak üzere genel itibariyle mollaların toplum içerisinde ciddi bir saygınlıklarının bulunduğu ve bu saygınlığa muvafık bir hayat tarzına sahip oldukları ifade edilebilir.

\section{Kaynakça}

\section{Arşiv Kaynakları}

Diyarbekir (Amid) Şer'iyye Sicilleri (DŞS), Başbakanlık Osmanlı Arşivi, Defter No:

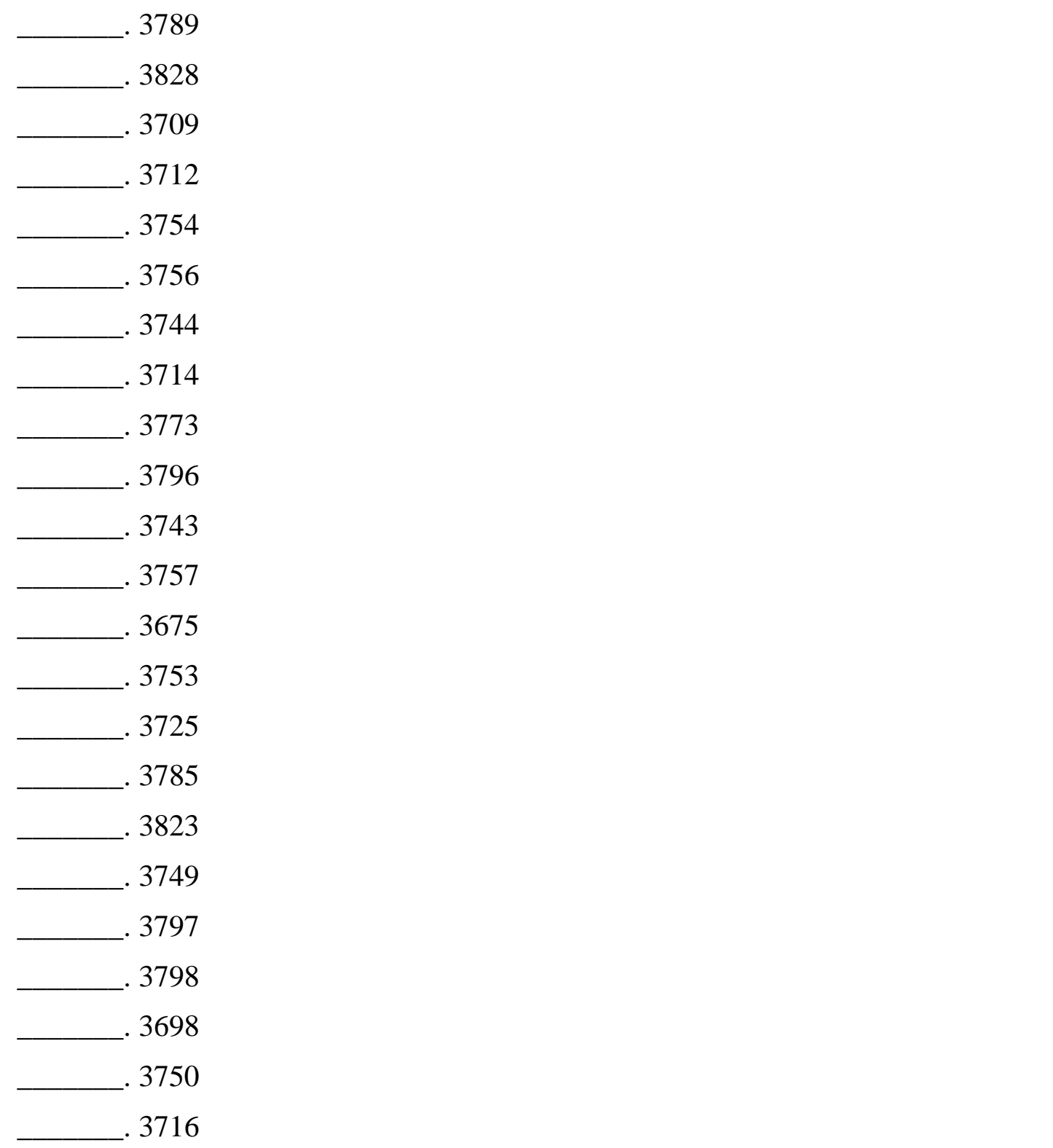


.3787

.3746

.3745

.3685

.3742

.3718

.3767

.3741

.3791

.3726

.3800

.3731

.3747

.3804

.3760

.3768

.3803

.3707

.3680

.3702

.3774

.3775

\section{Diğer Kaynaklar}

Acar, Abdurrahman. "Diyarbakır Medreseleri ve Osmanlı Eğitim Sistemi İçerisindeki Yerleri, Osmanlı'dan Cumhuriyet'e Diyarbakır. Ed. Bahaeddin Yediyıldız - Kerstin Tomenendal 1: 111-153. Ankara: Diyarbakır Valiliği, 2010.

Akdağ, Mustafa. Türkiye'nin İktisadî ve İçtimâ̂ Tarihi. İstanbul: Yapı Kredi Yayınları, 2010 .

Akgündüz, Ahmet. Şeri’yye Sicilleri. 2 Cilt. İstanbul: Türk Dünyası Araştırmaları Vakfi, 1988.

. "Başl1k". Türkiye Diyanet Vakfi İslâm Ansiklopedisi. 5: 131-133. İstanbul: TDV Yayınları, 1992.

Algar, Hamid. "Molla”. Türkiye Diyanet Vakfi İslâm Ansiklopedisi. 30: 238. İstanbul: TDV Yayınları, 2005.

Ali Emirî Efendi. Osmanlı Doğu Vilâyetleri. Haz. Abdulkadir Yuvalı - Ahmet Halaçoğlu. İstanbul: Babıali Kültür Yayıncılığı, 2015. 
Atar, Fahrettin. "Muhâlea". Türkiye Diyanet Vakfi İslâm Ansiklopedisi. 30: 399-402. İstanbul: TDV Yayınları, 2005.

Atay, Hüseyin. "Fatih Süleymaniye Medreseleri Ders Programları ve İcazetnameler". Vaklflar Dergisi 13 (1981): 171-235.

Aydın, M. Âkif. İslam-Osmanlı Aile Hukuku. İstanbul: Marmara Üni. İlahiyat Fak. Vakfı Yayınları, 1985.

Azimli, Mehmet. Diyarbakır ve Çevresinin Müslümanlaşma Süreci. Konya: Çizgi Kitapevi Yay., 2010.

Bala, Sabahattin. Bir Eğitim Kurumu Olarak Şark Medreseleri (Mardin Yöresi Örneği). Yüksek Lisans Tezi, Dicle Üni., 2012.

Bruinessen, Martin Van. A $\breve{g} a$, Şeyh, Devlet, Trc. Banu Yalkut. İstanbul: İletişim Yayınları, 2011.

Calmard J.. "Mollā”, The Encyclopedia of Islam, 7: 221-223. Leiden: E.J. Brill, 1980.

Cihan, Ahmet Kamil. "Fatih Dönemi İlim Hayatı ve Hocazâde". Uluslararası Hocazâde Sempozyumu Bildirileri (Bursa, 22-24 Ekim 2010). Ed. Tevfik Yücedoğru v.dğr. 59-85. Bursa: Bursa Büyükşehir Belediyesi Yayınları, 2011.

Çetin, Osman. Sicillere Göre Bursa'da İhtida Hareketleri ve Sosyal Sonuçları (14721909). Ankara: Türk Tarih Kurumu Basımevi, 1994.

Çiçek, Halil. Şark Medreselerinin Serencamı. İstanbul: Beyan Yayınları, 2009.

Dabashi, Hamid. "Mullah", The Oxford Encyclopedia of the Modern Islamic World. Ed. John L. Esposito - v.dğr. 3: 177. New York: Oxford University, 1995.

Demirtaş, Mehmet. Osmanlı Esnafinda Suç ve Ceza, Ankara: Birleşik Yay., 2010.

Devellioğlu, Ferid. Osmanlıca-Türkçe Ansiklopedik Lûgat. Ankara: Aydın Kitapevi, 2010.

Diyarbekir Şer ‘iyye Sicilleri Âmid Mahkemesi. Ed. Ahmet Zeki İzgöer. I-X. Diyarbakır: Dicle Üniversitesi İlahiyat Fakültesi Yayınları, 2013.

Ekinci, Ekrem Buğra. Osmanlı Hukuku. İstanbul: Arı Sanat Yay., 2012.

Erdoğan, Mehmet. Fıkıh ve Hukuk Terimleri Sözlüğü. İstanbul: Ensar Neşriyat, 2005.

Evliya Çelebi. Evliya Çelebi Seyahatnamesi. Haz. Seyit Ali Kahraman - Yücel Dağlı İstanbul: Yap1 Kredi Yayınları, 2010.

Göyünç, Nejat. "Diyarbakır”. Türkiye Diyanet Vakfı İslâm Ansiklopedisi. 9: 464-469. İstanbul: TDV Yayınları, 1994.

Güler, Ümit. "XVII. Yüzyıl Kıbrıs Kadı Sicilleri Işı̆̆ında Osmanlı Kıbrısı'nda "Evliliğin Sona Ermesi"”, Marmara Üniversitesi İlâhiyat Fakültesi Dergisi 52/52 (Haziran 2017): 61-93.

İpşirli, Mehmet. "Lakap". Türkiye Diyanet Vakfı İslâm Ansiklopedisi. 27:67. Ankara: TDV Yayınları, 2003.

Jennings, Ronald C.. Studies on Ottoman Social History in the Sixteenth and Seventeenth Centuries: Women, Zimmis and Sharia Courts in Kayseri, Cyprus and Trabzon. İstanbul: The Isis Press, 1999. 
Kurt, Abdurrahman. Bursa Sicillerine Göre Osmanlı Ailesi (1839-1876). Bursa: Uludăg Üniversitesi Basımevi, 1998.

Özcoşar, İbrahim. "Bir İslam ve Osmanlı Şehri Olarak Diyarbakır/Amid". Osmanlı'dan Günümüze Diyarbakır. Ed. İbrahim Özcoşar v.dğr., İstanbul: Ensar Yay., 2018.

Pakalın, Mehmet Zeki. "Molla”. Osmanlı Tarih Deyimleri ve Terimleri Sözlüğü. 2: 549. İstanbul: Milli Eğitim Basımevi, 1993.

Pekasil, Tahir. "Toplumsal Statü Göstergesi Olarak Dini Otorite Tipleri: Cizre Örneğinde Şeyh, Molla ve Seyyidler”. Uluslararası Bilim Düşünce ve Sanatta Cizre Seтроzуити Bildirileri 2012. Ed. M. Nesim Doru. İstanbul: 2012.

Subaş1, Necdet. "Şeyh, Seyyid ve Molla -Doğu ve Güneydoğu Anadolu Örneğinde Dinsel İtibarın Kategorileri”. İslâmiyât 2/3 (1999): 121-140.

Taş, Hülya. "Osmanlı Kad1 Mahkemesindeki "Şühûdü'l-Hâl” Nasıl Değerlendirilebilir?”. bilig 44 (Kış, 2008): 25-44.

Taş, Kenan Ziya. Tarih Işı̆̆ıında Güneydoğu ve Diyarbakır. Ankara: Berikan Yayınevi, 2012.

Uğur, Yunus. "Şer'iyye Sicilleri”. Türkiye Diyanet Vakfı İslâm Ansiklopedisi. 39: 8-11. İstanbul: TDV Yayınları, 2010.

Unan, Fahri. "Mevleviyet". Türkiye Diyanet Vakfi İslâm Ansiklopedisi. 29: 467-468. Ankara: TDV Yayınları, 2004.

Uzunçarşıll, İsmail Hakkı. "Şer'î Mahkeme Sicilleri”, Ülkü Halkevleri Dergisi 5/29 (Temmuz 1935): 365-368.

1988.

Osmanlı Devleti’nin Ilmiye Teşkilâtı. Ankara: Türk Tarih Kurumu Basımevi,

Verhei, Jelle. - Aydın, Suavi. "Diyarbekir Vilâyetinde Etnik-Dinî Gruplar, Yerel Güçler ve Osmanlı Devleti Üzerine Birkaç Not (1800-1870)". Osmanlı Döneminde Diyarbekir'de Toplumsal İlişkiler (1870-1915). Ed. Joost Jongerden - Jelle Verheij. Çev. Ayşen Gür. İstanbul: İstanbul Bilgi Üniversitesi Yayınları, 2015.

Yaman, T. Mümtaz, "Şer‘î Mahkeme Sicilleri”, Ülkü Halkevleri Dergisi 12/68 (İlk Teşrin 1938): 153-164.

Yediyıldız, Bahaeddin. “Osmanlı Öncesi Diyarbakır'ına Genel Bir Bakış”. Osmanlı'dan Cumhuriyet'e Diyarbakir. Ed. Bahaeddin Yediyıldiz - Kerstin Tomenendal. Ankara: Diyarbakır Valiliği, 2010.

Yılmazçelik, İbrahim. XIX. Yüzyılın İlk Yarısında Diyarbakır (1790-1840). Ankara: Türk Tarih Kurumu Yay., 2014.

Zilfi, Madeline C.. "Geçinemiyoruz: 18. Yüzyılda Kadınlar ve Hul”, Modernleşmenin Eşiğinde Osmanlı Kadınları. Ed. Madeline C. Zilfi İstanbul: Tarih Vakfı Yurt Yayınları, 2014. 
Ek 1: Mollalara Ait Tereke Tablosu

\begin{tabular}{|c|c|c|c|c|c|c|c|c|c|}
\hline & İsim & Eş & Evlat & $\begin{array}{l}\text { Mahalle- } \\
\text { Köy }\end{array}$ & $\begin{array}{l}\text { Köle- } \\
\text { Cariye }\end{array}$ & $\begin{array}{l}\text { Kitap- } \\
\text { Divit }\end{array}$ & $\begin{array}{l}\text { Tereke } \\
\text { Meblağı }\end{array}$ & Yll & Belge \\
\hline 1 & $\begin{array}{l}\text { Molla } \\
\text { Rasül b. } \\
\text { Mustafa }\end{array}$ & $\begin{array}{l}\text { Âişe bt. } \\
\text { Yusuf }\end{array}$ & - & $\begin{array}{l}\text { Derviş } \\
\text { Hüseyin } \\
\text { Mahallesi }\end{array}$ & 1 & - & $\begin{array}{l}40.164 \\
\text { Akçe }\end{array}$ & 1169 & $\begin{array}{l}3744 \\
(7 b-1)\end{array}$ \\
\hline 2 & $\begin{array}{l}\text { Molla } \\
\text { İbrahim } \\
\text { b. Hasan }\end{array}$ & $\begin{array}{l}\text { Âişe bt. } \\
\text { Bayram } \\
\text { ve } \\
\text { Hadice } \\
\text { bt. Ali }\end{array}$ & 2 & $\begin{array}{l}\text { Dağ Kapısı } \\
\text { hâricinde } \\
\text { vâki‘ } \\
\text { Ortaköy }\end{array}$ & - & - & $\begin{array}{l}113.742 \\
\text { Akçe }\end{array}$ & 1169 & $\begin{array}{l}3744 \\
(11 b- \\
2)\end{array}$ \\
\hline 3 & $\begin{array}{l}\text { Molla } \\
\text { Osman b. } \\
\text { Ömer }\end{array}$ & $\begin{array}{l}\text { Nimet } \\
\text { bt. Ömer }\end{array}$ & 1 & $\begin{array}{l}\text { Veli } \\
\text { Kethüda } \\
\text { Mahallesi }\end{array}$ & - & - & Guremâ & 1172 & $\begin{array}{l}3796 \\
(7 b-1)\end{array}$ \\
\hline 4 & $\begin{array}{l}\text { Molla } \\
\text { Süleyman } \\
\text { b. } \\
\text { Şeyhmus }\end{array}$ & $\begin{array}{l}\text { Fâtıma } \\
\text { bt. Rasül }\end{array}$ & 2 & $\begin{array}{l}\text { Câmiu's- } \\
\text { Safâ } \\
\text { Mahallesi }\end{array}$ & - & - & $\begin{array}{l}2.341 \\
\text { Para }\end{array}$ & 1172 & $\begin{array}{l}3796 \\
(12 a- \\
1)\end{array}$ \\
\hline 5 & $\begin{array}{l}\text { Cennân } \\
\text { Monla } \\
\text { Kasım b. } \\
\text { Monla } \\
\text { Halid }\end{array}$ & $\begin{array}{l}\text { Fâtıma } \\
\text { bt. } \\
\text { İsmail }\end{array}$ & 3 & $\begin{array}{l}\text { Fatih } \\
\text { Mehmed } \\
\text { Paşa Camii } \\
\text { Mahallesi }\end{array}$ & - & $\begin{array}{l}\text { Mushaf } \\
\text {-1 Şerîf }\end{array}$ & $\begin{array}{l}2.122 \\
\text { Kuruş }\end{array}$ & 1173 & $\begin{array}{l}3796 \\
(31 a- \\
1)\end{array}$ \\
\hline 6 & $\begin{array}{l}\text { Neccâr } \\
\text { Molla } \\
\text { Hüseyin } \\
\text { b. } \\
\text { Mehmed }\end{array}$ & $\begin{array}{l}\text { Huri bt. } \\
\text { Halil ve } \\
\text { Âişe bt. } \\
\text { Mehmed }\end{array}$ & 2 & $\begin{array}{l}\text { Na'lçaci } \\
\text { Mahallesi }\end{array}$ & - & Kitâblar & $\begin{array}{l}\text { Borç ve } \\
\text { masraflar } \\
\text { ödendi. } \\
\text { Kalan } \\
\text { yok. }\end{array}$ & 1173 & $\begin{array}{l}3796 \\
(32 a- \\
2)\end{array}$ \\
\hline 7 & $\begin{array}{l}\text { Seyyid } \\
\text { Monla } \\
\text { Mehmed } \\
\text { b. Seyyid } \\
\text { Fazlı }\end{array}$ & $\begin{array}{l}\text { Fâtıma } \\
\text { bt. Aslan }\end{array}$ & - & $\begin{array}{l}\text { Hüseyin } \\
\text { Efendi } \\
\text { Mahallesi }\end{array}$ & - & - & $\begin{array}{l}18.540 \\
\text { Meblağ }\end{array}$ & 1173 & $\begin{array}{l}3796 \\
(58 a- \\
3)\end{array}$ \\
\hline 8 & $\begin{array}{l}\text { Aydınzâd } \\
\text { e Monla } \\
\text { Ahmed b. } \\
\text { Mehmed }\end{array}$ & $\begin{array}{l}\text { Hamide } \\
\text { bt. Safer }\end{array}$ & 1 & $\begin{array}{l}\text { Hüseyin } \\
\text { Efendi } \\
\text { Mahallesi }\end{array}$ & - & Kitâb & $\begin{array}{l}5.850 \\
\text { Meblağ }\end{array}$ & 1173 & $\begin{array}{l}3796 \\
(60 a- \\
1)\end{array}$ \\
\hline 9 & $\begin{array}{l}\text { Molla } \\
\text { Mustafa } \\
\text { b. Ali }\end{array}$ & $\begin{array}{l}\text { Fâtıma } \\
\text { bt. } \\
\text { Süleyma } \\
\text { n }\end{array}$ & 4 & $\begin{array}{l}\text { Hüsameddi } \\
\mathrm{n} \\
\text { Mahallesi }\end{array}$ & - & - & Guremâ & 1173 & $\begin{array}{l}3796 \\
(65 a- \\
3)\end{array}$ \\
\hline
\end{tabular}




\begin{tabular}{|c|c|c|c|c|c|c|c|c|c|}
\hline 10 & $\begin{array}{l}\text { Haffâf } \\
\text { Molla } \\
\text { Ahmed b. } \\
\text { Hacı } \\
\text { Süleyman }\end{array}$ & $\begin{array}{l}\text { Nimetull } \\
\text { ah bt. } \\
\text { Monla } \\
\text { Hüseyin }\end{array}$ & 1 & $\begin{array}{l}\text { İbn-i } \\
\text { Müderris } \\
\text { Mahallesi }\end{array}$ & - & $\begin{array}{l}\text { Çok } \\
\text { sayıda } \\
\text { kitap }^{82}\end{array}$ & $\begin{array}{l}1.189 \\
\text { Kuruş }\end{array}$ & 1173 & $\begin{array}{l}3796 \\
(67 b- \\
1)\end{array}$ \\
\hline 11 & $\begin{array}{l}\text { Monla } \\
\text { Osman b. } \\
\text { Ali' }\end{array}$ & $\begin{array}{l}\text { Huri bt. } \\
\text { Mehmed }\end{array}$ & 1 & $\begin{array}{l}\text { Rum } \\
\text { Kap1s1 } \\
\text { hâricinde } \\
\text { Ali karyesi }\end{array}$ & - & - & $\begin{array}{l}4.965 \\
\text { Meblağ }\end{array}$ & 1173 & $\begin{array}{l}3796 \\
(50 \mathrm{~b}- \\
2)\end{array}$ \\
\hline 12 & $\begin{array}{l}\text { Bakkāl } \\
\text { Molla } \\
\text { Mehmed } \\
\text { b. Ahmed }\end{array}$ & $\begin{array}{l}\text { Zeliha } \\
\text { bt. Hacı } \\
\text { Mustafa }\end{array}$ & 6 & $\begin{array}{l}\text { Mustafa } \\
\text { Paşa } \\
\text { Mahallesi }\end{array}$ & - & $\begin{array}{l}\text { Hadîs-i } \\
\text { şerîf, } \\
\text { Kelâm-1 } \\
\text { Kadîm } \\
83\end{array}$ & $\begin{array}{l}1.984 \\
\text { Kuruş } 33 \\
\text { Para }\end{array}$ & 1202 & $\begin{array}{l}3757 \\
(24 a- \\
2))\end{array}$ \\
\hline 13 & $\begin{array}{l}\text { Molla } \\
\text { Latif b. } \\
\text { Osman }\end{array}$ & $\begin{array}{l}\text { Emine } \\
\text { bt. Ali }\end{array}$ & 2 & $\begin{array}{l}\text { Ali Paşa } \\
\text { Mahallesi }\end{array}$ & - & - & $\begin{array}{l}441.5 \\
\text { Kuruş }\end{array}$ & 1203 & $\begin{array}{l}3757 \\
(42 \mathrm{~b}- \\
2)\end{array}$ \\
\hline 14 & $\begin{array}{l}\text { Bakkal } \\
\text { Molla } \\
\text { Mehmed } \\
\text { b. } \\
\text { Mustafa }\end{array}$ & $\begin{array}{l}\text { Ümmüha } \\
\text { ni bt. } \\
\text { Abdurra } \\
\text { hman }\end{array}$ & 4 & $\begin{array}{l}\text { Ali Paşa } \\
\text { Mahallesi }\end{array}$ & - & - & $\begin{array}{l}15.805 \\
\text { Para. }\end{array}$ & 1203 & $\begin{array}{l}3757 \\
(45 a- \\
1)\end{array}$ \\
\hline 15 & $\begin{array}{l}\text { Bostancı } \\
\text { Molla } \\
\text { Süleyman } \\
\text { b. } \\
\text { Abdullah }\end{array}$ & - & - & $\begin{array}{l}\text { Câmiu'n- } \\
\text { Nebî } \\
\text { Mahallesi }\end{array}$ & - & $\begin{array}{l}\text { Kelâm-1 } \\
\text { Kadîm }\end{array}$ & $\begin{array}{l}1.426 \\
\text { Para }\end{array}$ & 1204 & $\begin{array}{l}3753 \\
(19 a- \\
1)\end{array}$ \\
\hline 16 & $\begin{array}{l}\text { Molla } \\
\text { Mahmud } \\
\text { b. } \\
\text { Şeyhmus }\end{array}$ & $\begin{array}{l}\text { Zeliha } \\
\text { bt. } \\
\text { Mehmed }\end{array}$ & 4 & $\begin{array}{l}\text { Şeyh } \\
\text { Matar } \\
\text { Mahallesi }\end{array}$ & - & - & $\begin{array}{l}2.352 \\
\text { Para. }\end{array}$ & 1204 & $\begin{array}{l}3753 \\
(23 b- \\
1)\end{array}$ \\
\hline 17 & $\begin{array}{l}\text { Molla } \\
\text { Ahmed b. } \\
\text { Hacı } \\
\text { Emin } \\
\text { Efendi }\end{array}$ & $\begin{array}{l}\text { Zeliha } \\
\text { bt. Hacı } \\
\text { Ebubekir }\end{array}$ & - & $\begin{array}{l}\text { Hanzade } \\
\text { Hatun } \\
\text { Mahallesi }\end{array}$ & - & $\begin{array}{l}\text { Çok } \\
\text { sayıda } \\
\text { kitap, } \\
\text { divit ve } \\
\text { kâğıt }\end{array}$ & $\begin{array}{l}510,5 \\
\text { Kuruş. }\end{array}$ & 1206 & $\begin{array}{l}3725 \\
(67 b- \\
1)\end{array}$ \\
\hline 18 & $\begin{array}{l}\text { Seyyid } \\
\text { Molla } \\
\text { Bekir b. } \\
\text { Seyyid } \\
\text { el-Hâc }\end{array}$ & $\begin{array}{l}\text { Duha } \\
\text { Hâtûn bt. } \\
\text { Abdülke } \\
\text { rim }\end{array}$ & 2 & $\begin{array}{l}\text { Hanzade } \\
\text { Hatun } \\
\text { Mahallesi }\end{array}$ & - & - & $\begin{array}{l}2.573 \\
\text { Para } 1 \\
\text { Akçe }\end{array}$ & 1206 & $\begin{array}{l}3725 \\
(71 a- \\
2)\end{array}$ \\
\hline
\end{tabular}

82 “Mushaf-ı Şerîf, Vesîletü'n-Necât, Mültekā, Dürer, Eşbâh, Mebârık, Türkî Yusuf-Züleyha, Tefsîrü'lMe 'âlim, Meşârık, Nebe Tefsîri, İbrahim-i Halebî, Tefsîr-i Şerîf, Cevâhirüll-Fıkıh, Tarîkat, Türkî kitâb, Kadızâde, Kavâid-i I'râb, Şerh-i Ta'lîm Müte'allim, Kudûrî, Fenârî ma'a Kavl-i Ahmed, Nâ-tamâm Mültekā, Hulâsa ma 'a R̂̂znâme, Mecmû 'a'

${ }^{83}$ Kur'an-1 Kerim 


\begin{tabular}{|c|c|c|c|c|c|c|c|c|c|}
\hline & Ömer & & & & & & & & \\
\hline 19 & $\begin{array}{l}\text { Muhzır } \\
\text { Molla } \\
\text { Ahmed b. } \\
\text { Osman }\end{array}$ & $\begin{array}{l}\text { Fâtıma } \\
\text { bt. } \\
\text { Hasan }\end{array}$ & - & $\begin{array}{l}\text { Derviş } \\
\text { Hüseyin } \\
\text { Mahallesi }\end{array}$ & - & $\begin{array}{l}\text { Kelâm-1 } \\
\text { Kadîm }\end{array}$ & Guremâ & 1206 & $\begin{array}{l}3725 \\
(72 \mathrm{a}- \\
1)\end{array}$ \\
\hline 20 & $\begin{array}{l}\text { Molla } \\
\text { Mustafa } \\
\text { b. Ömer }\end{array}$ & $\begin{array}{l}\text { Zeliha } \\
\text { bt. } \\
\text { Süleyma } \\
\text { n ve } \\
\text { Hadice } \\
\text { bt. } \\
\text { Süleyma } \\
\text { n }\end{array}$ & 3 & $\begin{array}{l}\text { Molla } \\
\text { Bahaeddin } \\
\text { Mahallesi }\end{array}$ & - & $\begin{array}{l}\text { Az } \\
\text { sayıda } \\
\text { kitap ve } \\
\text { divit }\end{array}$ & $\begin{array}{l}3.250 \\
\text { Para }\end{array}$ & 1206 & $\begin{array}{l}3725 \\
(91 \mathrm{~b}- \\
1)\end{array}$ \\
\hline 21 & $\begin{array}{l}\text { Molla } \\
\text { Ebubekir } \\
\text { b. } \\
\text { Mehmed }\end{array}$ & $\begin{array}{l}\text { Emine } \\
\text { bt. } \\
\text { Süleyma } \\
\mathrm{n}\end{array}$ & 2 & $\begin{array}{l}\text { Şeref } \\
\text { Çavuş } \\
\text { Mahallesi }\end{array}$ & - & - & $\begin{array}{l}107,5 \\
\text { Kuruş } 5 \\
\text { Para }\end{array}$ & 1206 & $\begin{array}{l}3785 \\
(4 a-2)\end{array}$ \\
\hline 22 & $\begin{array}{l}\text { Molla Ali } \\
\text { b. Osman }\end{array}$ & $\begin{array}{l}\text { Emetulla } \\
\text { h bt. } \\
\text { Hac1 } \\
\text { İsmail }\end{array}$ & 7 & $\begin{array}{l}\text { Çakal } \\
\text { Mescidi } \\
\text { Mahallesi }\end{array}$ & - & - & $\begin{array}{l}1.002 \\
\text { Para }\end{array}$ & 1206 & $\begin{array}{l}3785 \\
(5 b-1)\end{array}$ \\
\hline 23 & $\begin{array}{l}\text { Molla } \\
\text { Osman b. } \\
\text { Mehmed }\end{array}$ & $\begin{array}{l}\text { Hacer bt. } \\
\text { Abuzer } \\
\text { ve } \\
\text { Hanım } \\
\text { bt. } \\
\text { Mehmed }\end{array}$ & 3 & $\begin{array}{l}\text { Ali Paşa } \\
\text { Mahallesi }\end{array}$ & - & - & $\begin{array}{l}2.095 \\
\text { Para }\end{array}$ & 1206 & $\begin{array}{l}3785 \\
(6 b-1)\end{array}$ \\
\hline 24 & $\begin{array}{l}\text { Molla } \\
\text { İsmail b. } \\
\text { Mehmed }\end{array}$ & $\begin{array}{l}\text { Saliha } \\
\text { bt. } \\
\text { Hüseyin }\end{array}$ & 2 & $\begin{array}{l}\text { Fatih } \\
\text { Mehmed } \\
\text { Paşa } \\
\text { Mahallesi }\end{array}$ & - & - & $\begin{array}{l}118 \\
\text { Kuruş } 1 \\
\text { rub، }\end{array}$ & 1206 & $\begin{array}{l}3785 \\
(17 \mathrm{a}- \\
1)\end{array}$ \\
\hline 25 & $\begin{array}{l}\text { Molla } \\
\text { Hasan b. } \\
\text { Hacı Ali }\end{array}$ & $\begin{array}{l}\text { Âişe bt. } \\
\text { Mehmed }\end{array}$ & 2 & $\begin{array}{l}\text { Aziz } \\
\text { Câmi'i } \\
\text { Mahallesi }\end{array}$ & - & - & $\begin{array}{l}5.432 \\
\text { Para }\end{array}$ & 1207 & $\begin{array}{l}3785 \\
(39 \mathrm{~b}- \\
2)\end{array}$ \\
\hline 26 & $\begin{array}{l}\text { Seyyid } \\
\text { Molla } \\
\text { Bekir b. } \\
\text { Mahmud } \\
\text { Efendi }\end{array}$ & $\begin{array}{l}\text { Hadice } \\
\text { bt. Sinan }\end{array}$ & - & $\begin{array}{l}\text { Na'lçeci } \\
\text { Mahallesi }\end{array}$ & - & $\begin{array}{l}\text { Çok } \\
\text { sayıda } \\
\text { kitap }^{84}\end{array}$ & $\begin{array}{l}588 \\
\text { Kuruş }\end{array}$ & 1207 & $\begin{array}{l}3785 \\
(54 \mathrm{~b}- \\
1)\end{array}$ \\
\hline 27 & $\begin{array}{l}\text { Molla } \\
\text { Osman b. } \\
\text { Ahmed }\end{array}$ & $\begin{array}{l}\text { Zeyneb } \\
\text { bt. } \\
\text { Mehmed }\end{array}$ & - & $\begin{array}{l}\text { Rum } \\
\text { Kapis1 } \\
\text { hâricinde } \\
\text { Alipınar1 } \\
\text { karyesi }\end{array}$ & - & $\begin{array}{l}\text { Kitaplar } \\
\text { Kelâm-1 } \\
\text { Kadîm }\end{array}$ & $\begin{array}{l}13.873 \\
\text { Para. }\end{array}$ & 1214 & $\begin{array}{l}3797 \\
(2 a-1)\end{array}$ \\
\hline
\end{tabular}

84 “Kelâm-ı Kadîm, Mülteka'l-ebhur, Keşfü'l-ğita ve hafa, Ihtiyâr sâir, Kavl-i Ahmed-i Fenârî", 


\begin{tabular}{|c|c|c|c|c|c|c|c|c|c|}
\hline 28 & $\begin{array}{l}\text { Molla } \\
\text { Mehmed } \\
\text { b. Molla } \\
\text { İbrahim }\end{array}$ & $\begin{array}{l}\text { Âişe bt. } \\
\text { İbrahim } \\
\text { Ağa }\end{array}$ & - & $\begin{array}{l}\text { Fatih } \\
\text { Mehmed } \\
\text { Paşa } \\
\text { Mahallesi }\end{array}$ & - & $\begin{array}{l}\text { Çok } \\
\text { sayıda } \\
\text { kitap }^{85}\end{array}$ & $\begin{array}{l}602,5 \\
\text { Kuruş } 5 \\
\text { Para }\end{array}$ & 1214 & $\begin{array}{l}3797(1 \\
1 b-1)\end{array}$ \\
\hline 29 & $\begin{array}{l}\text { Molla } \\
\text { Mehmed } \\
\text { b. Ali }\end{array}$ & $\begin{array}{l}\text { Esma bt. } \\
\text { Hacı } \\
\text { Eyüb }\end{array}$ & 1 & $\begin{array}{l}\text { Yiğit } \\
\text { Ahmed } \\
\text { Mahallesi }\end{array}$ & - & $\begin{array}{l}\text { Şirâzî } \\
\text { ve } \\
\text { evrâk-1 } \\
\text { Kitaplar }\end{array}$ & $\begin{array}{l}10.211 \\
\text { Para }\end{array}$ & 1215 & $\begin{array}{l}3797- \\
14 b-1\end{array}$ \\
\hline 30 & $\begin{array}{l}\text { Neccâr } \\
\text { Molla } \\
\text { Yusuf b. } \\
\text { Mustafa }\end{array}$ & $\begin{array}{l}\text { Âdile bt. } \\
\text { Molla } \\
\text { Mustafa }\end{array}$ & 3 & $\begin{array}{l}\text { Rabia } \\
\text { Hâtûn } \\
\text { Mahallesi }\end{array}$ & - & - & 80 Kuruş & 1220 & $\begin{array}{l}3716 \\
(6 a-1)\end{array}$ \\
\hline 31 & $\begin{array}{l}\text { Molla } \\
\text { Hüseyin } \\
\text { b. } \\
\text { Mehmed }\end{array}$ & $\begin{array}{l}\text { Âdile bt. } \\
\text { Mehmed }\end{array}$ & 1 & $\begin{array}{l}\text { Câmiu'n- } \\
\text { Nebî } \\
\text { Mahallesi }\end{array}$ & - & - & Guremâ & 1220 & $\begin{array}{l}3716 \\
(8 a-2)\end{array}$ \\
\hline 32 & $\begin{array}{l}\text { Tarakçı } \\
\text { Molla } \\
\text { Hasan b. } \\
\text { Hüseyin }\end{array}$ & $\begin{array}{l}\text { Râhile } \\
\text { bt. Molla } \\
\text { Ali }\end{array}$ & 2 & $\begin{array}{l}\text { İskender } \\
\text { Paşa } \\
\text { Mahallesi }\end{array}$ & - & Divitler & $\begin{array}{l}286 \\
\text { Kuruş. }\end{array}$ & 1220 & $\begin{array}{l}3716 \\
(10 \mathrm{~b}- \\
2)\end{array}$ \\
\hline 33 & $\begin{array}{l}\text { Monla } \\
\text { Ahmed b. } \\
\text { Abdi }\end{array}$ & $\begin{array}{l}\text { Âişe bt. } \\
(?)\end{array}$ & - & $\begin{array}{l}\text { Veli } \\
\text { Kethüda } \\
\text { Mahallesi }\end{array}$ & - & - & $\begin{array}{l}120,5 \\
\text { Kuruş }\end{array}$ & 1220 & $\begin{array}{l}3716 \\
(13 a- \\
2)\end{array}$ \\
\hline 34 & $\begin{array}{l}\text { Cennân } \\
\text { Molla Ali } \\
\text { b. Hacı } \\
\text { Rasül }\end{array}$ & $\begin{array}{l}\text { Meryem } \\
\text { bt. Halil }\end{array}$ & 1 & $\begin{array}{l}\text { Hoca } \\
\text { Ahmed-i } \\
\text { Müslim } \\
\text { Mahallesi }\end{array}$ & - & - & $\begin{array}{l}1.021 \\
\text { Kuruş. }\end{array}$ & 1220 & $\begin{array}{l}3716 \\
(16 \mathrm{~b}- \\
2)\end{array}$ \\
\hline 35 & $\begin{array}{l}\text { Debbâğ } \\
\text { Molla } \\
\text { Hüseyin } \\
\text { b. Ali }\end{array}$ & $\begin{array}{l}\text { Bahtiyar } \\
\text { bt. Ali }\end{array}$ & 5 & $\begin{array}{l}\text { Şeref } \\
\text { Çavuş } \\
\text { Mahallesi }\end{array}$ & - & - & $\begin{array}{l}468 \\
\text { Kuruş }\end{array}$ & 1220 & $\begin{array}{l}3716 \\
(23 \mathrm{a}- \\
2)\end{array}$ \\
\hline 36 & $\begin{array}{l}\text { Molla } \\
\text { Hüseyin } \\
\text { b. } \\
\text { Abdullah }\end{array}$ & $\begin{array}{l}\text { Âişe bt. } \\
\text { Molla } \\
\text { Ahmed }\end{array}$ & - & $\begin{array}{l}\text { Abdulaziz } \\
\text { Câmii } \\
\text { Mahallesi }\end{array}$ & - & $\begin{array}{l}\text { Kelâm-1 } \\
\text { Kadîm } \\
\text { ve } \\
\text { muhteli } \\
\text { f } \\
\text { kitaplar }\end{array}$ & Guremâ & 1221 & $\begin{array}{l}3716 \\
(26 a- \\
2)\end{array}$ \\
\hline 37 & $\begin{array}{l}\text { Monla } \\
\text { Ali b. }\end{array}$ & $\begin{array}{l}\text { Kafiye } \\
\text { bt. }\end{array}$ & 4 & $\begin{array}{l}\text { İskender } \\
\text { Paşa }\end{array}$ & - & $\begin{array}{l}\text { Kelâm-1 } \\
\text { Kadîm, }\end{array}$ & $\begin{array}{l}454 \\
\text { Kuruş } 2\end{array}$ & 1221 & $\begin{array}{l}3716 \\
(27 \mathrm{~b}-\end{array}$ \\
\hline
\end{tabular}

85 "Kelâm-ı Kadîm, Defa Kelâm-ı Kadîm, Evrâk-ı perîşân, Kâfiye, Mesâbîh-i şerîf, Vesîle, Va'ziye, Tefsîr$i$ şerîf, Abdurrahim Paşa ale'l-Mültekā, Seyyid Ferâiz, Halebî, Şerh-i Miftâh, Vankulu cildeyn, Hâşsiye-i Mutavvel, Muhtasar Müntehî, Hubeysî Şerh-i Kâfiye, Zübdetü'l-Esrâr, Isâm Tasdîkāt, Netâicü'l-Efkâr, Isâm Câmî, Felâh, Kavâ'idü'l-İ'râb, Mutavvel, İzhâr, Avâmil-i Misbâh, Şerh-i Gülşan, Kâfiye Dibâcezâde, Şerh-i Birgivî, Bostân Gülistân, Elfiye Şerh-i Enmûzec, Ebu'l-Münteha, Tefsîr-i Nebe, Evrâkı perîşân, Mev 'ize, Gülistân, Şerhu'l-Beyân, Hafiz-ı Şirâzî, En 'âm-ı şerîf, Cümle-i Sarf, Hüsniye, Kütüb-i müteferrika 7 cild, Surre'l-fetâvâ" 


\begin{tabular}{|c|c|c|c|c|c|c|c|c|c|}
\hline & İbrahim & Abdullah & & Mahallesi & & $\begin{array}{l}\text { En‘âm-1 } \\
\text { şerîf, } \\
\text { Mevlûd } \\
\text {-i şerîf }\end{array}$ & Para. & & 2) \\
\hline 38 & $\begin{array}{l}\text { Monla } \\
\text { İsmail b. } \\
\text { Mumcu } \\
\text { İsmail }\end{array}$ & $\begin{array}{l}\text { Fâtıma } \\
\text { bt. } \\
\text { Mustafa }\end{array}$ & 2 & $\begin{array}{l}\text { Bahaeddin } \\
\text { Mahallesi }\end{array}$ & - & - & $\begin{array}{l}184,5 \\
\text { Kuruş. }\end{array}$ & 1221 & $\begin{array}{l}3716 \\
(29 a- \\
1)\end{array}$ \\
\hline 39 & $\begin{array}{l}\text { Haffâf } \\
\text { Monla } \\
\text { Mustafa } \\
\text { b. el-Hâc } \\
\text { Ahmed }\end{array}$ & $\begin{array}{l}\text { Zeliha } \\
\text { bt. Hacı } \\
\text { Ali }\end{array}$ & - & $\begin{array}{l}\text { Kastal } \\
\text { Mahallesi }\end{array}$ & - & - & $\begin{array}{l}1.524 \\
\text { Kuruş } 1 \\
\text { rub` } 9^{6} \\
\text { Para. }\end{array}$ & 1221 & $\begin{array}{l}3716 \\
(35 b- \\
1)\end{array}$ \\
\hline 40 & $\begin{array}{l}\text { Molla } \\
\text { Halil b. } \\
\text { Hasan }\end{array}$ & $\begin{array}{l}\text { Hamide } \\
\text { bt. } \\
\text { Osman }\end{array}$ & 3 & $\begin{array}{l}\text { Hoca } \\
\text { Ahmed } \\
\text { Mahallesi }\end{array}$ & - & - & $\begin{array}{l}222,5 \\
\text { Kuruş }\end{array}$ & 1221 & $\begin{array}{l}3716 \\
(39 b- \\
1)\end{array}$ \\
\hline 41 & $\begin{array}{l}\text { Berber } \\
\text { Monla } \\
\text { Ali b. } \\
\text { İbrahim }\end{array}$ & $\begin{array}{l}\text { Havva } \\
\text { bt. } \\
\text { İsmail }\end{array}$ & 2 & $\begin{array}{l}\text { Molla } \\
\text { Bahaeddin } \\
\text { Mahallesi }\end{array}$ & - & $\begin{array}{l}\text { Kelâm-1 } \\
\text { Kadîm }\end{array}$ & $\begin{array}{l}117,5 \\
\text { Kuruş } 8 \\
\text { Para. }\end{array}$ & 1221 & $\begin{array}{l}3716 \\
(40 b- \\
1)\end{array}$ \\
\hline 42 & $\begin{array}{l}\text { Çüngüşlü } \\
\text { Molla } \\
\text { Hüseyin } \\
\text { b. } \\
\text { Abdullah }\end{array}$ & - & - & $\begin{array}{l}\text { Medrese-i } \\
\text { Mesudiye' } \\
\text { de sâkin }\end{array}$ & - & - & 46 Kuruş & & $\begin{array}{l}3685 \\
(1 a-2)\end{array}$ \\
\hline 43 & $\begin{array}{l}\text { Kanbur } \\
\text { Molla } \\
\text { Mahmud } \\
\text { b. Yusuf }\end{array}$ & $\begin{array}{l}\text { Emine } \\
\text { bt. } \\
\text { Mehmed }\end{array}$ & - & $\begin{array}{l}\text { Göl } \\
\text { Mescidi } \\
\text { Mahallesi }\end{array}$ & - & - & $\begin{array}{l}612 \\
\text { Kuruş } 1 \\
\text { rub، }\end{array}$ & 1239 & $\begin{array}{l}3685 \\
(9 a-2)\end{array}$ \\
\hline 44 & $\begin{array}{l}\text { Kul } \\
\text { Kâtibi } \\
\text { Molla } \\
\text { Abdurrah } \\
\text { man }\end{array}$ & $\begin{array}{l}\text { Muhsine } \\
\text { bt. Hâfız } \\
\text { Osman }\end{array}$ & - & $\begin{array}{l}\text { İmadiye } \\
\text { Mahallesi }\end{array}$ & - & $\begin{array}{l}\text { Kelâm-1 } \\
\text { Kadîm, } \\
\text { kitaplar, } \\
\text { Divitler } \\
\text {. }\end{array}$ & $\begin{array}{l}1.820 \\
\text { Kuruş }\end{array}$ & 1239 & $\begin{array}{l}3685 \\
(9 b-1)\end{array}$ \\
\hline 45 & $\begin{array}{l}\text { Molla Ali } \\
\text { b. Hasan }\end{array}$ & $\begin{array}{l}\text { Hanife } \\
\text { bt. } \\
\text { Mehmed }\end{array}$ & 2 & $\begin{array}{l}\text { Kilbaş } \\
\text { Mescidi } \\
\text { Mahallesi }\end{array}$ & - & - & $\begin{array}{l}412 \\
\text { Kuruş }\end{array}$ & 1240 & $\begin{array}{l}3685 \\
(17 a- \\
1)\end{array}$ \\
\hline 46 & $\begin{array}{l}\text { Molla } \\
\text { İbrahim } \\
\text { b. } \\
\text { Abdullah }\end{array}$ & - & - & $\begin{array}{l}\text { Tabanoğlu } \\
\text { Mescidi } \\
\text { Mahallesin } \\
\text { de Nasuh } \\
\text { Paşa } \\
\text { Câmii'ne } \\
\text { bitişik } \\
\text { medresede } \\
\text { sâkin }\end{array}$ & - & - & $\begin{array}{l}137 \\
\text { Kuruş } 13 \\
\text { Para }\end{array}$ & 1240 & $\begin{array}{l}3685 \\
(17 a- \\
2)\end{array}$ \\
\hline 47 & $\begin{array}{l}\text { Penbeci } \\
\text { Molla }\end{array}$ & Vesile & 3 & $\begin{array}{l}\text { Câmiu's- } \\
\text { Safâ }\end{array}$ & - & - & Guremâ & 1240 & $\begin{array}{l}3685 \\
(20 a- \\
\end{array}$ \\
\hline
\end{tabular}




\begin{tabular}{|c|c|c|c|c|c|c|c|c|c|}
\hline & $\begin{array}{l}\text { Mustafa } \\
\text { b. } \\
\text { İbrahim' }\end{array}$ & & & Mahallesi & & & & & 2) \\
\hline 48 & $\begin{array}{l}\text { Bezzâz } \\
\text { Molla } \\
\text { Abdullah } \\
\text { b. İsmail' }\end{array}$ & $\begin{array}{l}\text { Hamide } \\
\text { bt. Haci } \\
\text { Yusuf ile } \\
\text { Emetulla } \\
\text { h bt. } \\
\text { Abdullah }\end{array}$ & 4 & $\begin{array}{l}\text { Cami-i } \\
\text { Kebir } \\
\text { Mahallesi }\end{array}$ & - & - & $\begin{array}{l}2.757,5 \\
\text { Kuruş } 1 \\
\text { rub، }\end{array}$ & 1240 & $\begin{array}{l}3685 \\
(30 a- \\
1)\end{array}$ \\
\hline 49 & $\begin{array}{l}\text { Penbeci } \\
\text { Molla } \\
\text { Mustafa } \\
\text { b. Hac1 } \\
\text { Mehmed }\end{array}$ & $\begin{array}{l}\text { Fâtıma } \\
\text { bt. Ömer }\end{array}$ & 2 & $\begin{array}{l}\text { Memeddin } \\
\text { Mescidi } \\
\text { Mahallesi }\end{array}$ & - & - & $\begin{array}{l}282 \\
\text { Kuruş }\end{array}$ & 1240 & $\begin{array}{l}3685 \\
(30 \mathrm{~b}- \\
1)\end{array}$ \\
\hline 50 & $\begin{array}{l}\text { Kırbacizâ } \\
\text { de Molla } \\
\text { İbrahim }\end{array}$ & $\begin{array}{l}\text { Elif ve } \\
\text { Fatıma }\end{array}$ & - & - & - & - & $\begin{array}{l}175,5 \\
\text { Kuruş } 15 \\
\text { Para }\end{array}$ & - & $\begin{array}{l}3742 \\
(1 \mathrm{a}-3)\end{array}$ \\
\hline 51 & $\begin{array}{l}\text { Molla } \\
\text { Süleyman } \\
\text { b. } \\
\text { Mustafa }\end{array}$ & $\begin{array}{l}\text { Rukiye } \\
\text { bt. Ömer } \\
\text { Efendi } \\
\text { ve } \\
\text { Hadice } \\
\text { bt. } \\
\text { Mehmed }\end{array}$ & 3 & $\begin{array}{l}\text { Kamışlı } \\
\text { Mescidi } \\
\text { Mahallesi }\end{array}$ & - & $\begin{array}{l}\text { Kelâm-1 } \\
\text { Kadîm }\end{array}$ & $\begin{array}{l}61 \text { Kuruş } \\
5 \text { Para. }\end{array}$ & 1237 & $\begin{array}{l}3742 \\
(8 a-2)\end{array}$ \\
\hline 52 & $\begin{array}{l}\text { Molla } \\
\text { Hasan b. } \\
\text { Mehmed } \\
\text { Emin }\end{array}$ & - & - & $\begin{array}{l}\text { Derviş̧ } \\
\text { Hüseyin } \\
\text { Mahallesi }\end{array}$ & - & Divitler & $\begin{array}{l}443 \\
\text { Kuruş. }\end{array}$ & 1238 & $\begin{array}{l}3742 \\
(17 \mathrm{a}- \\
2)\end{array}$ \\
\hline 53 & $\begin{array}{l}\text { Molla } \\
\text { Nebi b. } \\
\text { Hacı } \\
\text { Mustafa }\end{array}$ & - & - & $\begin{array}{l}\text { Fatih } \\
\text { Mehmed } \\
\text { Paşa Câmi- } \\
\text { i Şerîfi'nde } \\
\text { medresede } \\
\text { sâkin }\end{array}$ & - & $\begin{array}{l}\text { Muharr } \\
\text { er kitâb } \\
1 \text { cild, } \\
\text { kitap } 3 \\
\text { cild. }\end{array}$ & $\begin{array}{l}245 \\
\text { Kuruş } 1 \\
\text { rub` } 6 \\
\text { Para }\end{array}$ & 1238 & $\begin{array}{l}3742 \\
(18 b- \\
1)\end{array}$ \\
\hline 54 & $\begin{array}{l}\text { Molla } \\
\text { Mehmed } \\
\text { Ağa b. } \\
\text { Maksud } \\
\text { Ağa }\end{array}$ & $\begin{array}{l}\text { İmiş } \\
\text { Hâtûn bt. } \\
\text { Rasül }\end{array}$ & 1 & $\begin{array}{l}\text { Alican } \\
\text { Mahallesi }\end{array}$ & - & - & $\begin{array}{l}1.113 \\
\text { Kuruş } 3 \\
\text { rub‘ } 3 \\
\text { Para }\end{array}$ & 1238 & $\begin{array}{l}3742 \\
(21 \mathrm{~b}- \\
1)\end{array}$ \\
\hline 55 & $\begin{array}{l}\text { Seyyid } \\
\text { Molla } \\
\text { Halil b. } \\
\text { Abdullah }\end{array}$ & - & - & $\begin{array}{l}\text { Cedîd } \\
\text { Hân'da } \\
\text { misafir }\end{array}$ & - & - & $\begin{array}{l}22,5 \\
\text { Kuruş } 7 \\
\text { Para. } \\
\text { (beytülm } \\
\text { al) }\end{array}$ & 1238 & $\begin{array}{l}3742 \\
(26 a- \\
1)\end{array}$ \\
\hline 56 & $\begin{array}{l}\text { Basmaci } \\
\text { Molla Ali } \\
\text { b. } \\
\text { Mustafa }\end{array}$ & $\begin{array}{l}\text { Hamide } \\
\text { bt. Ömer }\end{array}$ & 3 & $\begin{array}{l}\text { Kastal } \\
\text { Mahallesi }\end{array}$ & - & - & $\begin{array}{l}629 \\
\text { Kuruş } 3 \\
\text { rub } 2^{6} \\
\text { Para. }\end{array}$ & 1238 & $\begin{array}{l}3742 \\
(27 \mathrm{~b}- \\
1)\end{array}$ \\
\hline
\end{tabular}




\begin{tabular}{|c|c|c|c|c|c|c|c|c|c|}
\hline 57 & $\begin{array}{l}\text { Molla } \\
\text { Osman, } \\
\text { b. } \\
\text { Hüseyin }\end{array}$ & $\begin{array}{l}\text { Fâtıma } \\
\text { bt. } \\
\text { Abdullah }\end{array}$ & - & $\begin{array}{l}\text { Alican } \\
\text { Mahallesi }\end{array}$ & - & Kitaplar & $\begin{array}{l}170,5 \\
\text { Kuruş } 3 \\
\text { Para. }\end{array}$ & 1238 & $\begin{array}{l}3742 \\
(30 a- \\
1)\end{array}$ \\
\hline 58 & $\begin{array}{l}\text { Molla } \\
\text { Abdullah } \\
\text { b. Ali }\end{array}$ & $\begin{array}{l}\text { Firdevs } \\
\text { Hâtûn bt. } \\
\text { (?) }\end{array}$ & - & $\begin{array}{l}\text { Derviş } \\
\text { Hüseyin } \\
\text { Mahallesi }\end{array}$ & - & - & $\begin{array}{l}2.382,5 \\
\text { Kuruş } 2 \\
\text { Para. }\end{array}$ & 1238 & $\begin{array}{l}3742 \\
(37 \mathrm{~b}- \\
2)\end{array}$ \\
\hline 59 & $\begin{array}{l}\text { Bostânc1 } \\
\text { Pilav } \\
\text { Mustafa'n } \\
\text { 1n oğlu } \\
\text { Molla } \\
\text { Ömer }\end{array}$ & $\begin{array}{l}\text { Vesika } \\
\text { bt. el- } \\
\text { Hâc } \\
\text { Abdullah }\end{array}$ & 3 & $\begin{array}{l}\text { Memeddin } \\
\text { Mahallesi }\end{array}$ & - & - & $\begin{array}{l}382 \\
\text { Kuruş } 1 \\
\text { rub‘. }\end{array}$ & 1238 & $\begin{array}{l}3742 \\
(38 \mathrm{a}- \\
1)\end{array}$ \\
\hline 60 & $\begin{array}{l}\text { Keçeci } \\
\text { es-Seyyid } \\
\text { Molla } \\
\text { Sadullah } \\
\text { b. Molla } \\
\text { Mehmed }\end{array}$ & $\begin{array}{l}\text { Zeliha } \\
\text { bt. Halil }\end{array}$ & 4 & $\begin{array}{l}\text { Kamışlı } \\
\text { Mahallesi }\end{array}$ & - & - & $\begin{array}{l}1044 \\
\text { Kuruş } 12 \\
\text { Para. }\end{array}$ & 1239 & $\begin{array}{l}3742 \\
(40 \mathrm{~b}- \\
1) \text { ve } \\
\text { ayrica } \\
3742 \\
(42 \mathrm{a}- \\
1)\end{array}$ \\
\hline 61 & $\begin{array}{l}\text { Liceli } \\
\text { Molla } \\
\text { Ali' }\end{array}$ & Havva & - & $\begin{array}{l}\text { Fatih } \\
\text { Câmii'nde } \\
\text { sâkin }\end{array}$ & - & - & $\begin{array}{l}21 \text { Kuruş } \\
3 \text { rub` } 3 \\
\text { Para. }\end{array}$ & 1242 & $\begin{array}{l}3718 \\
(15 a- \\
2)\end{array}$ \\
\hline 62 & $\begin{array}{l}\text { Sofu } \\
\text { Molla } \\
\text { Mustafa } \\
\text { b. } \\
\text { Mehmed }\end{array}$ & Havva & - & $\begin{array}{l}\text { Abdal } \\
\text { Mahallesi }\end{array}$ & - & - & $\begin{array}{l}2.822,5 \\
\text { Kuruş } 3 \\
\text { Para. }\end{array}$ & 1243 & $\begin{array}{l}3718 \\
(30 \mathrm{~b}- \\
2)\end{array}$ \\
\hline 63 & $\begin{array}{l}\text { Haffâf } \\
\text { Aydınlızâ } \\
\text { de Molla } \\
\text { Mustafa }\end{array}$ & $\begin{array}{l}\text { Emine } \\
\text { bt. Sagir }\end{array}$ & 2 & $\begin{array}{l}\text { Kılbaşı } \\
\text { Mahallesi }\end{array}$ & - & $\begin{array}{l}\text { Gülistâ } \\
\text { n, } \\
\text { Hadîs-i } \\
\text { Buhari } \\
\text { Hâfız } \\
\text { ve } \\
\text { Hayâlî }\end{array}$ & $\begin{array}{l}3.972 \\
\text { Kuruş }\end{array}$ & 1154 & $\begin{array}{l}3718(6 \\
a-1)\end{array}$ \\
\hline 64 & $\begin{array}{l}\text { Eskici } \\
\text { Molla } \\
\text { Hüseyin } \\
\text { b. Aşur }\end{array}$ & $\begin{array}{l}\text { Âişe bt. } \\
\text { Mato ve } \\
\text { Meryem } \\
\text { bt. } \\
\text { Abdullah } \\
\text { ve Bahar } \\
\text { bt. } \\
\text { Ahmed }\end{array}$ & - & $\begin{array}{l}\text { Na'lcçeci } \\
\text { Mahallesi }\end{array}$ & - & - & $\begin{array}{l}23.786 \\
\text { Kuruş }\end{array}$ & 1154 & $\begin{array}{l}3718 \\
(12 \mathrm{a}- \\
2)\end{array}$ \\
\hline 65 & $\begin{array}{l}\text { Molla } \\
\text { Halil b. } \\
\text { Kalender' }\end{array}$ & $\begin{array}{l}\text { Hanife } \\
\text { bt. } \\
\text { Mehmed }\end{array}$ & 2 & $\begin{array}{l}\text { Ali Paşa } \\
\text { Mahallesi }\end{array}$ & - & - & $\begin{array}{l}19.649 \\
\text { Kuruş }\end{array}$ & 1154 & $\begin{array}{l}3718 \\
(20 \mathrm{a}- \\
3)\end{array}$ \\
\hline 66 & $\begin{array}{l}\text { Molla Ali } \\
\text { b. Nebe }\end{array}$ & $\begin{array}{l}\text { Hadice } \\
\text { bt. }\end{array}$ & 2 & $\begin{array}{l}\text { Derûn-1 } \\
\text { kal'ada }\end{array}$ & - & - & Guremâ & 1155 & $\begin{array}{l}3718 \\
(28 \mathrm{a}-\end{array}$ \\
\hline
\end{tabular}




\begin{tabular}{|c|c|c|c|c|c|c|c|c|c|}
\hline & & Kasım & & sâkin & & & & & 1) \\
\hline 67 & $\begin{array}{l}\text { Molla } \\
\text { Yusuf }\end{array}$ & Hadîce & 1 & $\begin{array}{l}\text { İbrahim } \\
\text { Bey } \\
\text { Mahallesi }\end{array}$ & - & - & $\begin{array}{l}144 \\
\text { Kuruş } 3 \\
\text { rub" }\end{array}$ & 1246 & $\begin{array}{l}3741(3 \\
a-1)\end{array}$ \\
\hline 68 & $\begin{array}{l}\text { Molla } \\
\text { İbrahim }\end{array}$ & $\begin{array}{l}\text { Emine } \\
\text { Hâtûn }\end{array}$ & 1 & $\begin{array}{l}\text { İskender } \\
\text { Paşa } \\
\text { Mahallesi }\end{array}$ & - & - & $\begin{array}{l}662 \\
\text { Kuruş }\end{array}$ & 1246 & $\begin{array}{l}3741 \\
(3 a-2)\end{array}$ \\
\hline 69 & $\begin{array}{l}\text { Bezzâz } \\
\text { Molla } \\
\text { Hasan }\end{array}$ & $\begin{array}{l}\text { Vedia } \\
\text { Hâtûn }\end{array}$ & 3 & - & - & $\begin{array}{l}\text { Kelâm-1 } \\
\text { Kadîm } \\
2 \text { adet }\end{array}$ & $\begin{array}{l}2.958,5 \\
\text { Kuruş }\end{array}$ & 1247 & $\begin{array}{l}3741 \\
(19 a- \\
2)\end{array}$ \\
\hline 70 & $\begin{array}{l}\text { Bâkî kulu } \\
\text { Molla } \\
\text { Hüseyin }\end{array}$ & - & - & $\begin{array}{l}\text { Tanirzeli } \\
\text { olup } \\
\text { Câmi‘-i } \\
\text { Kebîr'de } \\
\text { vefat etti }\end{array}$ & - & - & $\begin{array}{l}13,5 \\
\text { Kuruş }\end{array}$ & 1252 & $\begin{array}{l}3726 \\
(1 \mathrm{a}-2)\end{array}$ \\
\hline 71 & $\begin{array}{l}\text { Cüllâh } \\
\text { Molla } \\
\text { Emin }\end{array}$ & Âişe & 1 & $\begin{array}{l}\text { Ali Paşa } \\
\text { Mahallesi }\end{array}$ & - & - & $\begin{array}{l}2.345 \\
\text { Kuruş }\end{array}$ & 1252 & $\begin{array}{l}3726 \\
(7 a-1)\end{array}$ \\
\hline 72 & $\begin{array}{l}\text { Monla } \\
\text { Mehmed } \\
\text { b. Ali }\end{array}$ & Emine & - & $\begin{array}{l}\text { Kavas-1 } \\
\text { Sağîr } \\
\text { Mahallesi }\end{array}$ & - & - & $\begin{array}{l}600 \\
\text { Kuruş. }\end{array}$ & 1252 & $\begin{array}{l}3726 \\
(10 b- \\
1)\end{array}$ \\
\hline 73 & $\begin{array}{l}\text { Molla } \\
\text { Koroğlu } \\
\text { Mustafa }\end{array}$ & hadice & 1 & $\begin{array}{l}\text { Fatih } \\
\text { Mahallesi }\end{array}$ & - & - & $\begin{array}{l}188.5 \\
\text { Kuruş }\end{array}$ & 1252 & $\begin{array}{l}3726 \\
(21 b- \\
1)\end{array}$ \\
\hline 74 & $\begin{array}{l}\text { Mardinli } \\
\text { Monla } \\
\text { Mesud }\end{array}$ & Âişe & - & $\begin{array}{l}\text { Derviş̧ } \\
\text { Hüseyin } \\
\text { Mahallesi }\end{array}$ & - & - & $\begin{array}{l}226 \\
\text { Kuruş. }\end{array}$ & 1252 & $\begin{array}{l}3726 \\
(32 a- \\
2)\end{array}$ \\
\hline 75 & $\begin{array}{l}\text { Molla } \\
\text { Bekir }\end{array}$ & Âişe & 3 & $\begin{array}{l}\text { Hanzâde } \\
\text { Mahallesi }\end{array}$ & - & - & $\begin{array}{l}2.257 \\
\text { Kuruş. }\end{array}$ & 1252 & $\begin{array}{l}3726 \\
(33 b- \\
1)\end{array}$ \\
\hline 76 & $\begin{array}{l}\text { Monla } \\
\text { Abdülgaf } \\
\text { ur b. } \\
\text { Ebubekir } \\
\text { Ağa }\end{array}$ & Fâtıma & 2 & $\begin{array}{l}\text { Yiğid } \\
\text { Ahmed } \\
\text { Mescidi } \\
\text { Mahallesi }\end{array}$ & - & $\begin{array}{l}\text { Kelâm-1 } \\
\text { Kadîm, } \\
\text { divitler }\end{array}$ & $\begin{array}{l}27.558,5 \\
\text { Kuruş. }\end{array}$ & 1256 & $\begin{array}{l}3747 \\
(19 b- \\
1)\end{array}$ \\
\hline 77 & $\begin{array}{l}\text { Tütüncül } \\
\text { er Şeyhi } \\
\text { Molla } \\
\text { Hüseyin }\end{array}$ & Muhsine & 3 & $\begin{array}{l}\text { Câmi' }{ }^{6} \text { i } \\
\text { Kebîr } \\
\text { Mahallesi }\end{array}$ & - & - & $\begin{array}{l}2.900 \\
\text { Kuruş }\end{array}$ & 1256 & $\begin{array}{l}3747 \\
(24 b- \\
1)\end{array}$ \\
\hline 78 & $\begin{array}{l}\text { Bayrakdâ } \\
\text { r Molla } \\
\text { Hüseyin }\end{array}$ & $\begin{array}{l}\text { Zeyneb } \\
\text { bt. } \\
\text { Mahmud }\end{array}$ & 5 & $\begin{array}{l}\text { Kastal } \\
\text { Camii } \\
\text { Mahallesi }\end{array}$ & - & - & $\begin{array}{l}7.526,5 \\
\text { Kuruş }\end{array}$ & 1261 & $\begin{array}{l}3768 \\
(39 a- \\
1)\end{array}$ \\
\hline 79 & $\begin{array}{l}\text { Molla } \\
\text { Hüseyin }\end{array}$ & Güllü bt. & 3 & $\begin{array}{l}\text { Kadi } \\
\text { Camii }\end{array}$ & - & - & $\begin{array}{l}14.438 \\
\text { Kuruş } 30\end{array}$ & 1261 & $\begin{array}{l}3768 \\
(46 a-\end{array}$ \\
\hline
\end{tabular}




\begin{tabular}{|c|c|c|c|c|c|c|c|c|c|}
\hline & $\begin{array}{l}\text { b. Hacı } \\
\text { Abdullah }\end{array}$ & Abdullah & & Mahallesi & & & Para & & 1) \\
\hline 80 & $\begin{array}{l}\text { Cennânân } \\
\text { Molla } \\
\text { Ragıb b. } \\
\text { Molla } \\
\text { Mustafa }\end{array}$ & $\begin{array}{l}\text { Barbara } \\
\text { bt. } \\
\text { Abdullah } \\
\text { ve } \\
\text { Fâtıma } \\
\text { bt. } \\
\text { Mustafa } \\
\text { Ağa }\end{array}$ & 1 & $\begin{array}{l}\text { Hacı Hizır } \\
\text { Mescidi } \\
\text { Mahallesi }\end{array}$ & - & - & Guremâ & 1261 & $\begin{array}{l}3768 \\
(62 \mathrm{a}- \\
1)\end{array}$ \\
\hline 81 & $\begin{array}{l}\text { Çerçi } \\
\text { Molla } \\
\text { Yusuf b. } \\
\text { Ali }\end{array}$ & $\begin{array}{l}\text { Meryem } \\
\text { bt. } \\
\text { Hasan }\end{array}$ & - & $\begin{array}{l}\text { Alican } \\
\text { Mescidi } \\
\text { Mahallesi }\end{array}$ & - & $\begin{array}{l}\text { Kelâm-1 } \\
\text { Kadîm, } \\
\text { En`âm }\end{array}$ & $\begin{array}{l}353 \\
\text { Kuruş. }\end{array}$ & 1264 & $\begin{array}{l}3707 \\
(2 a-1)\end{array}$ \\
\hline 82 & $\begin{array}{l}\text { Mücellid } \\
\text { Molla } \\
\text { Mustafa } \\
\text { b. Molla } \\
\text { Yusuf' }\end{array}$ & $\begin{array}{l}\text { Beriyye } \\
\text { bt. } \\
\text { Hüseyin }\end{array}$ & 1 & $\begin{array}{l}\text { İskender } \\
\text { Paşa } \\
\text { Mahallesi }\end{array}$ & - & $\begin{array}{l}1 \text { adet } \\
\text { kitap }\end{array}$ & $\begin{array}{l}406 \\
\text { Kuruş. }\end{array}$ & 1264 & $\begin{array}{l}3707 \\
(15 a- \\
1)\end{array}$ \\
\hline 83 & $\begin{array}{l}\text { Oturakçı } \\
\text { Molla } \\
\text { Mehmed } \\
\text { b. } \\
\text { Mustafa }\end{array}$ & $\begin{array}{l}\text { Âişe bt. } \\
\text { Ömer }\end{array}$ & 1 & $\begin{array}{l}\text { Kaş1k } \\
\text { Budak } \\
\text { Mescidi } \\
\text { Mahallesi }\end{array}$ & - & $\begin{array}{l}\text { Kelâm-1 } \\
\text { Kadîm }\end{array}$ & $\begin{array}{l}8.991 \\
\text { Kuruş. }\end{array}$ & 1264 & $\begin{array}{l}3707(3 \\
2 b-1)\end{array}$ \\
\hline 84 & $\begin{array}{l}\text { Merkebçi } \\
\text { Molla } \\
\text { Hasan b. } \\
\text { Mahmud }\end{array}$ & $\begin{array}{l}\text { Huri bt. } \\
\text { Hasan }\end{array}$ & 5 & $\begin{array}{l}\text { Çakal } \\
\text { Mescidi } \\
\text { Mahallesi }\end{array}$ & - & - & $\begin{array}{l}1.911,5 \\
\text { Kuruş. }\end{array}$ & 1264 & $\begin{array}{l}3707 \\
(39 b- \\
1)\end{array}$ \\
\hline 85 & $\begin{array}{l}\text { Molla } \\
\text { Ahmed b. } \\
\text { Şeyhmus }\end{array}$ & $\begin{array}{l}\text { Ünzile } \\
\text { bt. } \\
\text { Mustafa }\end{array}$ & 1 & $\begin{array}{l}\text { Alican } \\
\text { Mahallesi }\end{array}$ & - & $\begin{array}{l}\text { Mesâbi } \\
\text { h-i } \\
\text { şerîf, } 1 \\
\text { aded }\end{array}$ & $\begin{array}{l}563 \\
\text { Kuruş } 1 \\
\text { rub، }\end{array}$ & 1265 & $\begin{array}{l}3707 \\
(50 \mathrm{~b}- \\
3)\end{array}$ \\
\hline 86 & $\begin{array}{l}\text { Cennân } \\
\text { Molla } \\
\text { Ahmed b. } \\
\text { Şerif }\end{array}$ & $\begin{array}{l}\text { Meryem } \\
\text { bt. } \\
\text { Abdullah }\end{array}$ & 6 & $\begin{array}{l}\text { Abdal } \\
\text { Mescidi } \\
\text { Mahallesi }\end{array}$ & - & - & $\begin{array}{l}713,5 \\
\text { Kuruş. }\end{array}$ & 1265 & $\begin{array}{l}3707(6 \\
6 a-1)\end{array}$ \\
\hline 87 & $\begin{array}{l}\text { Monla } \\
\text { Mehmed } \\
\text { b. Hasan }\end{array}$ & $\begin{array}{l}\text { Rukiye } \\
\text { bt. Hacı } \\
\text { Esad }\end{array}$ & 3 & $\begin{array}{l}\text { İbn-i } \\
\text { Müderris } \\
\text { Mescidi } \\
\text { Mahallesi }\end{array}$ & $\begin{array}{l}\text { Câriye } \\
\text { bahâ } \\
1.150 \\
\text { Kuruş? }\end{array}$ & $\begin{array}{l}\text { Şâfi‘î̀ } \\
25 \\
\text { Kuruş }\end{array}$ & $\begin{array}{l}1.219,5 \\
\text { Kuruş. }\end{array}$ & 1265 & $\begin{array}{l}3707 \\
(97 b- \\
1)\end{array}$ \\
\hline 88 & $\begin{array}{l}\text { Penbeci } \\
\text { Monla } \\
\text { Yusuf b. } \\
\text { Mehmed }\end{array}$ & $\begin{array}{l}\text { Havva } \\
\text { bt. } \\
\text { Mehmed }\end{array}$ & 3 & $\begin{array}{l}\text { Abdal } \\
\text { Mescidi } \\
\text { Mahallesi }\end{array}$ & - & - & $\begin{array}{l}655 \\
\text { Kuruş } 1 \\
\text { rub،. }\end{array}$ & 1265 & $\begin{array}{l}3707 \\
(98 \mathrm{a}- \\
1)\end{array}$ \\
\hline 89 & $\begin{array}{l}\text { Monla } \\
\text { Bekir b. } \\
\text { Abdullah }\end{array}$ & $\begin{array}{l}\text { Fâtıma } \\
\text { bt. } \\
\text { Abdullah } \\
\text { ve Adile }\end{array}$ & 3 & $\begin{array}{l}\text { Murtaza } \\
\text { Paşa } \\
\text { Câmi'i }\end{array}$ & - & - & $\begin{array}{l}1.166 \\
\text { Kuruş } 3 \\
\text { rub،. }\end{array}$ & 1265 & $\begin{array}{l}3707 \\
(113 a- \\
3)\end{array}$ \\
\hline
\end{tabular}




\begin{tabular}{|c|c|c|c|c|c|c|c|c|c|}
\hline & & $\begin{array}{l}\text { bt. } \\
\text { Hasan }\end{array}$ & & Mahallesi & & & & & \\
\hline 90 & $\begin{array}{l}\text { Molla } \\
\text { Mehmed } \\
\text { b. Halid }\end{array}$ & $\begin{array}{l}\text { Elife bt. } \\
\text { Şeyhmus }\end{array}$ & - & $\begin{array}{l}\text { Câmiu'n- } \\
\text { Nebî } \\
\text { Mahallesi }\end{array}$ & - & - & $\begin{array}{l}584,5 \\
\text { Kuruş. }\end{array}$ & 1265 & $\begin{array}{l}3707 \\
(116 b- \\
1)\end{array}$ \\
\hline 91 & $\begin{array}{l}\text { Çerçi } \\
\text { Molla } \\
\text { Yusuf b. } \\
\text { Ali }\end{array}$ & $\begin{array}{l}\text { Meryem } \\
\text { bt. } \\
\text { Hasan }\end{array}$ & 1 & $\begin{array}{l}\text { Alican } \\
\text { Mescidi } \\
\text { Mahallesi }\end{array}$ & - & $\begin{array}{l}\text { Kelâm-1 } \\
\text { Kadîm, } \\
\text { En'âm }\end{array}$ & $\begin{array}{l}353 \\
\text { Kuruş. }\end{array}$ & 1264 & $\begin{array}{l}3707 \\
(2 a-1)\end{array}$ \\
\hline 92 & $\begin{array}{l}\text { Monla } \\
\text { Cafer b. } \\
\text { Abdülgaf } \\
\text { far }\end{array}$ & - & - & $\begin{array}{l}\text { Yeni } \\
\text { Hân'da } \\
\text { misafir }\end{array}$ & - & - & $\begin{array}{l}900 \\
\text { Kuruş. }\end{array}$ & 1266 & $\begin{array}{l}3707(1 \\
8 b-1)\end{array}$ \\
\hline 93 & $\begin{array}{l}\text { Molla Ali } \\
\text { b. } \\
\text { Hüseyin }\end{array}$ & $\begin{array}{l}\text { Fâtıma } \\
\text { bt. Halil } \\
\text { ve Âişe } \\
\text { bt. Ali }\end{array}$ & - & $\begin{array}{l}\text { Murtaza } \\
\text { Paşa } \\
\text { Mahallesi }\end{array}$ & - & - & $\begin{array}{l}45 \\
\text { Kuruş. }\end{array}$ & 1266 & $\begin{array}{l}3680 \\
(34 a- \\
2)\end{array}$ \\
\hline 94 & $\begin{array}{l}\text { Molla } \\
\text { Hasan b. } \\
\text { Abdullah' } \\
\text { in }\end{array}$ & $\begin{array}{l}\text { Âişe bt. } \\
\text { Mehmed }\end{array}$ & 3 & $\begin{array}{l}\text { Câmiu'n- } \\
\text { Nebî } \\
\text { Mahallesi }\end{array}$ & - & - & $\begin{array}{l}1.246 \\
\text { Kuruş. }\end{array}$ & 1267 & $\begin{array}{l}3680 \\
(35 b- \\
1)\end{array}$ \\
\hline 95 & $\begin{array}{l}\text { Monla } \\
\text { Mehmed } \\
\text { b. Monla } \\
\text { Hüseyin }\end{array}$ & $\begin{array}{l}\text { Fâtıma } \\
\text { bt. } \\
\text { Abdullah } \\
\text { ve } \\
\text { Medine } \\
\text { bt. } \\
\text { Fettah }\end{array}$ & 1 & $\begin{array}{l}\text { İskender } \\
\text { Paşa Camii } \\
\text { Mahallesi }\end{array}$ & - & - & $\begin{array}{l}2.609 \\
\text { Kuruş } 3 \\
\text { rub‘. }\end{array}$ & 1267 & $\begin{array}{l}3680 \\
(56 a- \\
1)\end{array}$ \\
\hline 96 & $\begin{array}{l}\text { Molla } \\
\text { Mehmed } \\
\text { b. } \\
\text { Mehmed }\end{array}$ & $\begin{array}{l}\text { Huri bt. } \\
\text { Ömer }\end{array}$ & 2 & $\begin{array}{l}\text { Hoca } \\
\text { Ahmed } \\
\text { Mahallesi }\end{array}$ & - & - & $\begin{array}{l}590 \\
\text { Kuruş } 30 \\
\text { Para }\end{array}$ & 1268 & $\begin{array}{l}3680 \\
(96 a- \\
2)\end{array}$ \\
\hline 97 & $\begin{array}{l}\text { Molla } \\
\text { Mehmed } \\
\text { b. } \\
\text { Abdullah }\end{array}$ & $\begin{array}{l}\text { Fâtıma } \\
\text { bt. Cuma }\end{array}$ & 4 & $\begin{array}{l}\text { Hoca } \\
\text { Ahmed } \\
\text { Mahallesi }\end{array}$ & - & - & $\begin{array}{l}2.816 \\
\text { Kuruş } 30 \\
\text { Para }\end{array}$ & 1268 & $\begin{array}{l}3680 \\
(97 \mathrm{a}- \\
2)\end{array}$ \\
\hline 98 & $\begin{array}{l}\text { Monla } \\
\text { Veli b. } \\
\text { Abdullah }\end{array}$ & - & 3 & $\begin{array}{l}\text { Kerh } \\
\text { Karyesi }\end{array}$ & - & - & - & 1268 & $\begin{array}{l}3702 \\
(7 a-1)\end{array}$ \\
\hline
\end{tabular}


Ek 2: Mollaların Mesleklerine Dair Tablo

\begin{tabular}{|c|c|c|c|c|c|c|}
\hline Meslek & Belge* & & & & & \\
\hline İmam & $\begin{array}{l}\text { DŞS, } 3828, \\
31 b-1 .\end{array}$ & & & & & \\
\hline Cami Hatibi & $\begin{array}{l}\text { DŞS, } 3709, \\
\text { 7b-2. }\end{array}$ & & & & & \\
\hline $\begin{array}{l}\text { Medrese } \\
\text { Kapicis1 }\end{array}$ & $\begin{array}{l}\text { DŞS, } 3754, \\
68 b-2 .\end{array}$ & & & & & \\
\hline Anbâr Kâtibi & $\begin{array}{l}\text { DŞS, } 3712, \\
37 b-4 .\end{array}$ & & & & & \\
\hline Kâtip & $\begin{array}{l}\text { DŞS, } 3789, \\
1 \mathrm{a}-2 .\end{array}$ & & & & & \\
\hline Berber & $\begin{array}{l}\text { DŞS, } 3828, \\
42 b-1 .\end{array}$ & & & & & \\
\hline Münâdî & $\begin{array}{l}\text { DŞS, } 3828, \\
2 b-1 .\end{array}$ & & & & & \\
\hline Nevbetçi & $\begin{array}{l}\text { DŞS, } 3828, \\
2 b-3 .\end{array}$ & & & & & \\
\hline Serrâc & $\begin{array}{l}\text { DŞS, } 3828, \\
3 \mathrm{a}-1 .\end{array}$ & & & & & \\
\hline Eskici & $\begin{array}{l}\text { DŞS, } 3828, \\
\text { 3b-1. }\end{array}$ & & & & & \\
\hline Lüleci & $\begin{array}{l}\text { DŞS, } 3828, \\
5 a-1 .\end{array}$ & & & & & \\
\hline Bezzâz & $\begin{array}{l}\text { DŞS, } 3828, \\
5 a-1 .\end{array}$ & & & & & \\
\hline Muhzır & $\begin{array}{l}\text { DŞS, } 3828, \\
11 \mathrm{~b}-3 .\end{array}$ & & & & & \\
\hline Ütücü & $\begin{array}{l}\text { DŞS, } 3709, \\
6 a-2 .\end{array}$ & & & & & \\
\hline Mektep Hocası & $\begin{array}{l}\text { DŞS, } 3712, \\
27 \mathrm{a}-3 .\end{array}$ & & & & & \\
\hline Attar & DŞS, 3712, & & & & & \\
\hline
\end{tabular}

* Mesleklerin yer aldığı belgelerin çok sayıda olması hasebiyle tespit edilen mesleklere dair birer kaynak zikredilmiştir. 


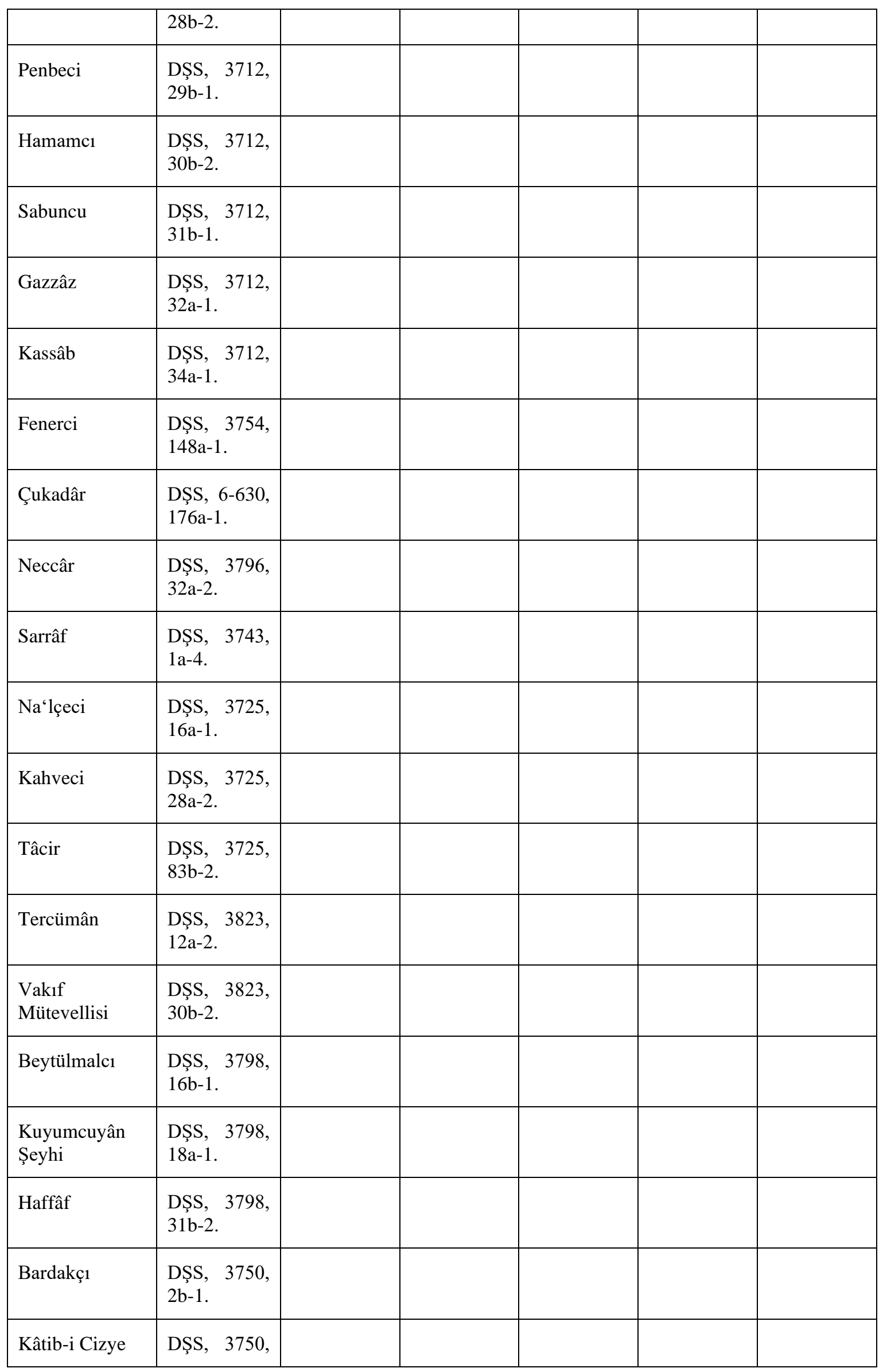




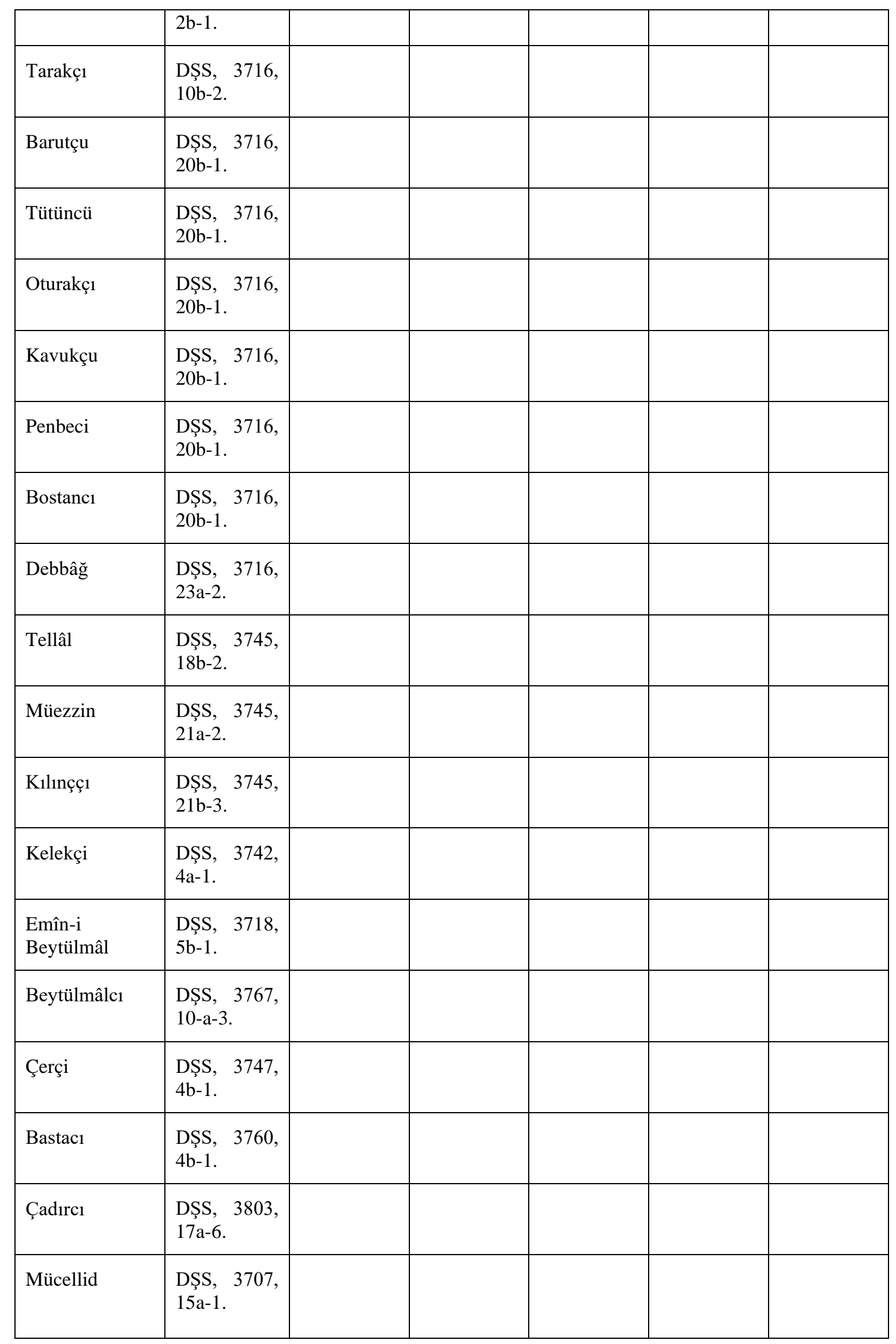




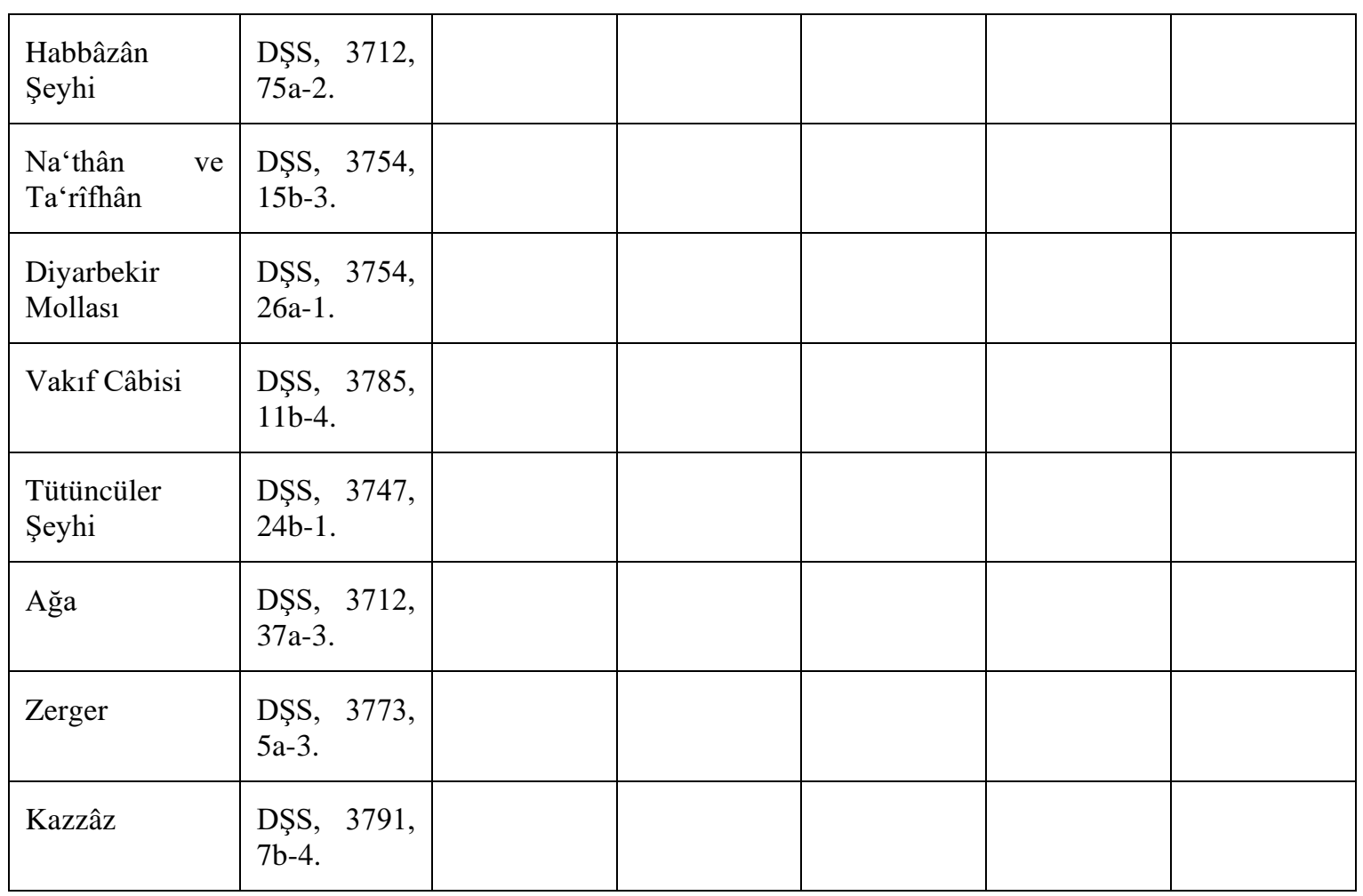

\section{Ek 3: Mollalara Dair Belge Örnekleri}

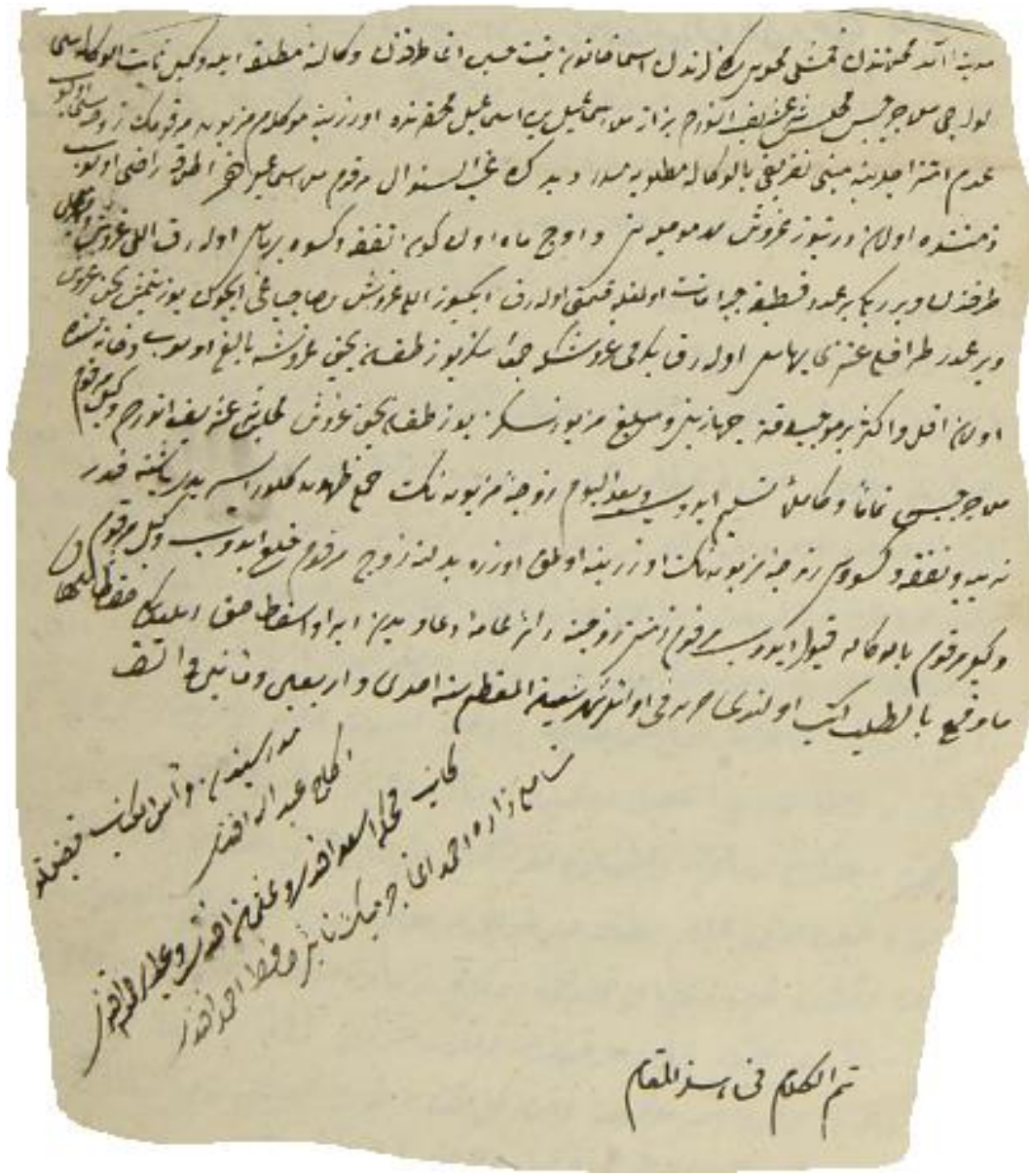

Belge 1: Bezzâz Molla İsmail ile hanımı Esma Hatun'un muhâlea yoluyla boşandıklarını tescil ettirmeleri (DŞS, 3828, 5a-1) 


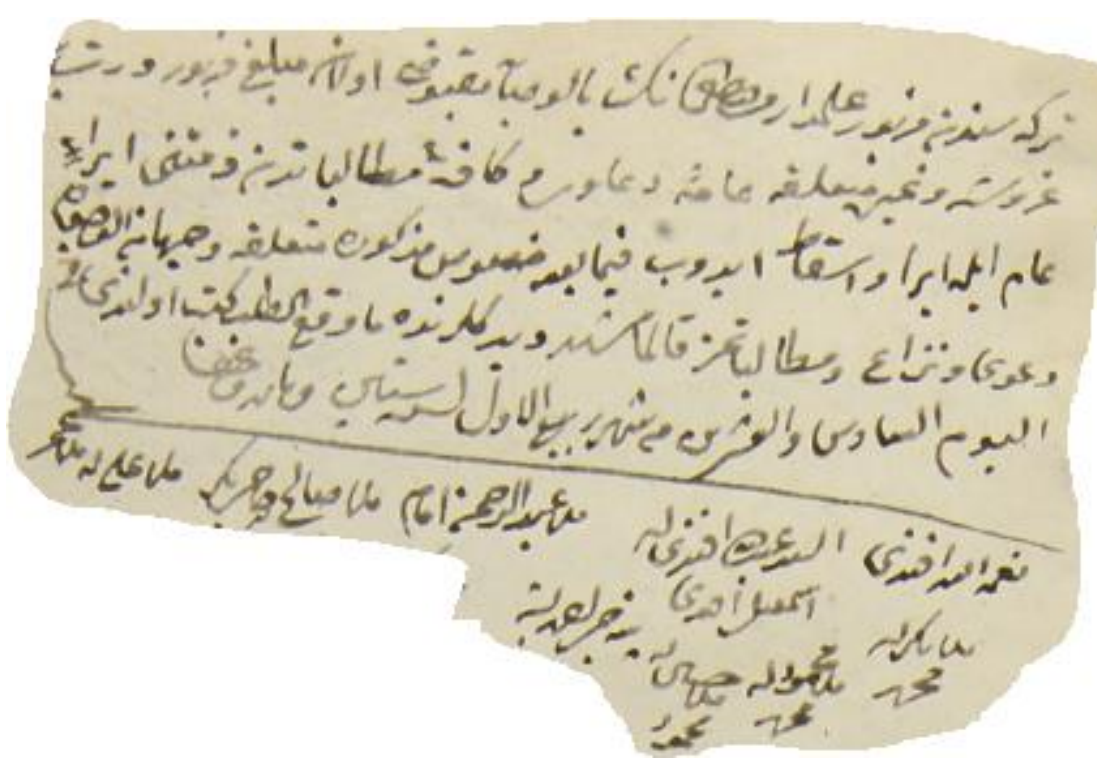

Belge 2: Sulh ile sonuçlanan bir tereke anlaşmazlığının tescilinde şühûdü'l-hâl olarak yer alan mollalar (DŞS, 3712, 72b-2)

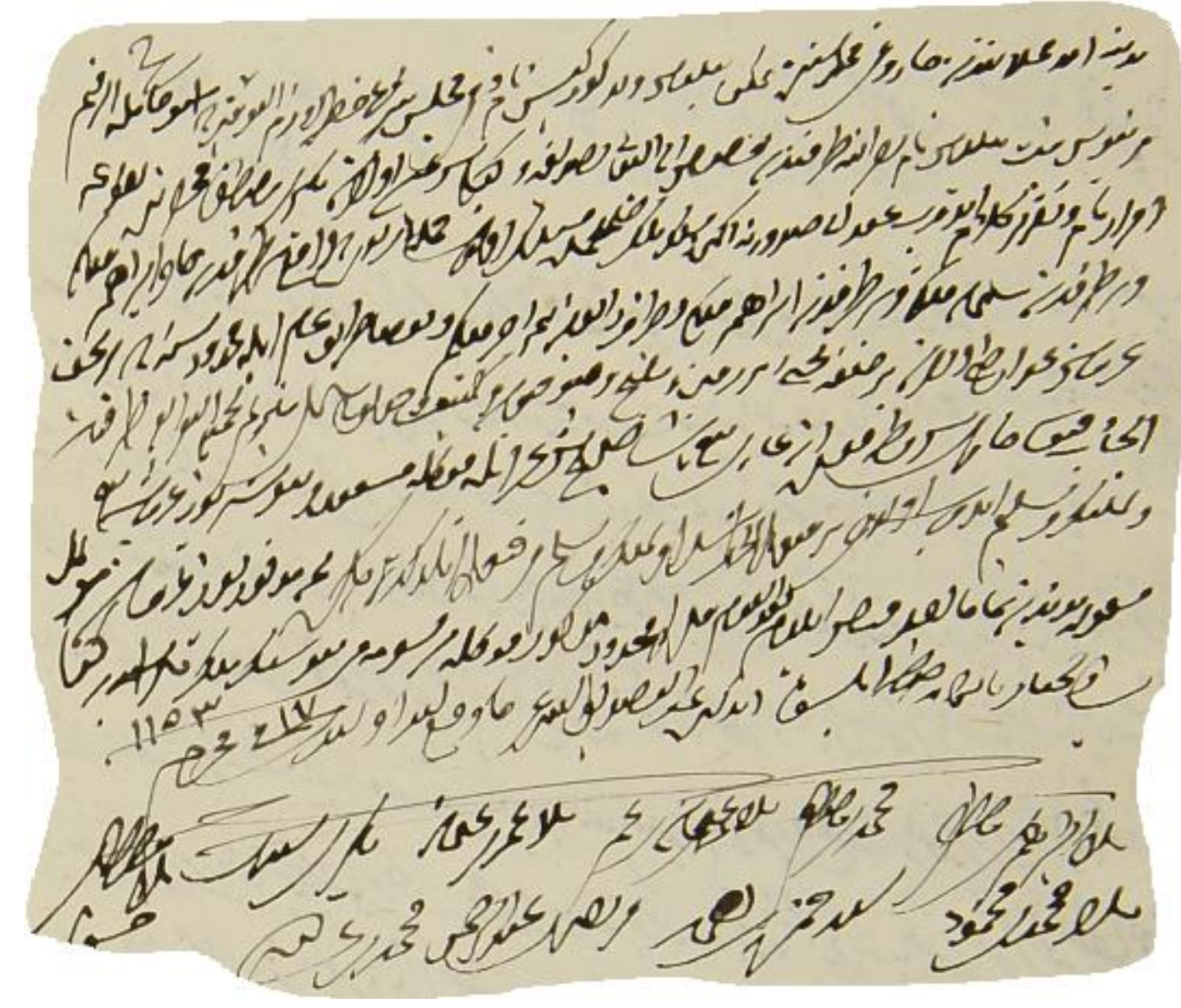

Belge 3: İki gayrimüslimin mülk alım satım tescilinde şühûdü’l-hâl olarak yer alan mollalar (DŞS, 3754, 157b-1) 


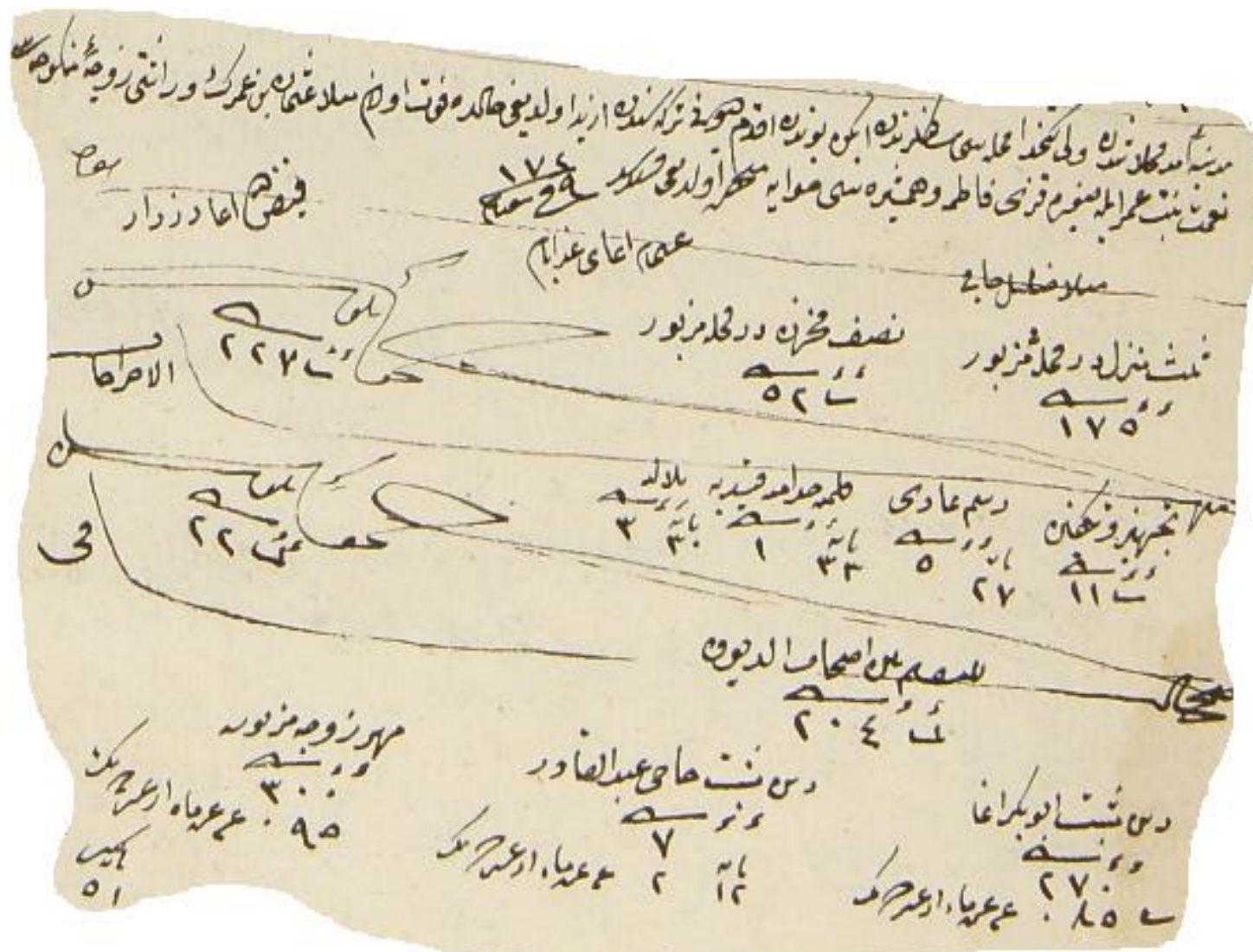

Belge 4: Borcu terekesinden fazla olan Molla Osman b. Ömer'in terekesinin guremâ usulüyle alacaklılara dağıtılması (DŞS, 3796, 7b-1)

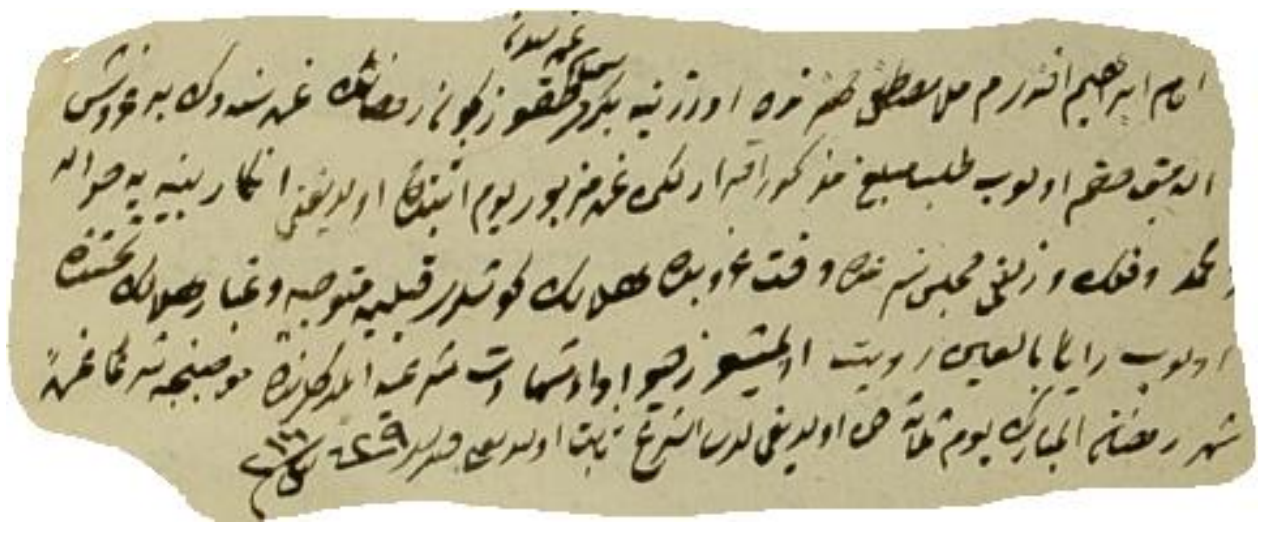

Belge 5: Alacaklı İmâm İbrahim Efendi ile borçlu Molla Mustafa arasındaki alacak verecek meselesi (DŞS, 3798, 6b-6) 


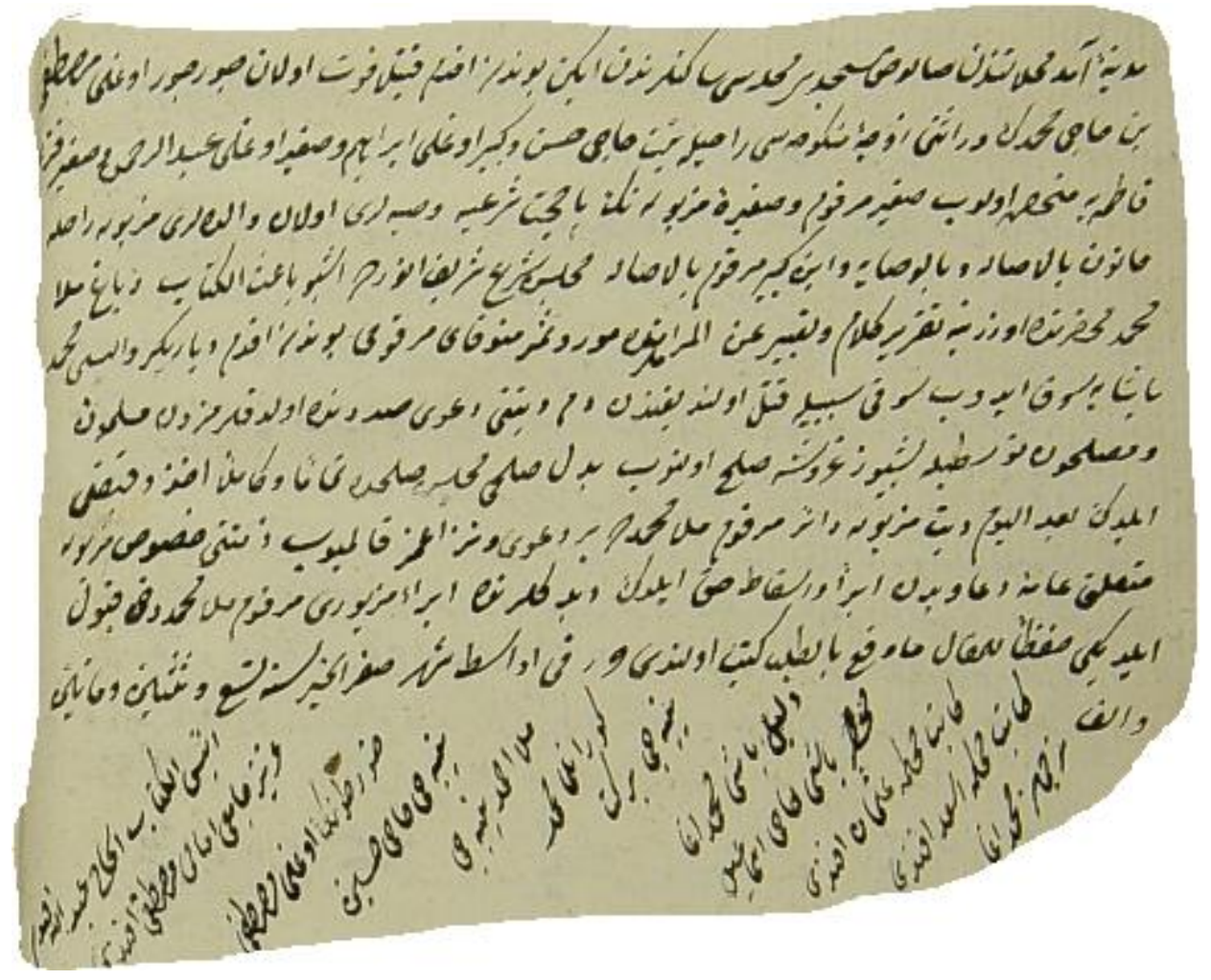

Belge 6: Kocasının ölümüne sebep olduğunu iddia ederek diyet talebinde bulunan Râhile bt. Hacı Hasan ile davalı Debbâğ Molla Mehmed'in 500 kuruş üzerine sulh oldukları (DŞS, 3745, 13b-1)

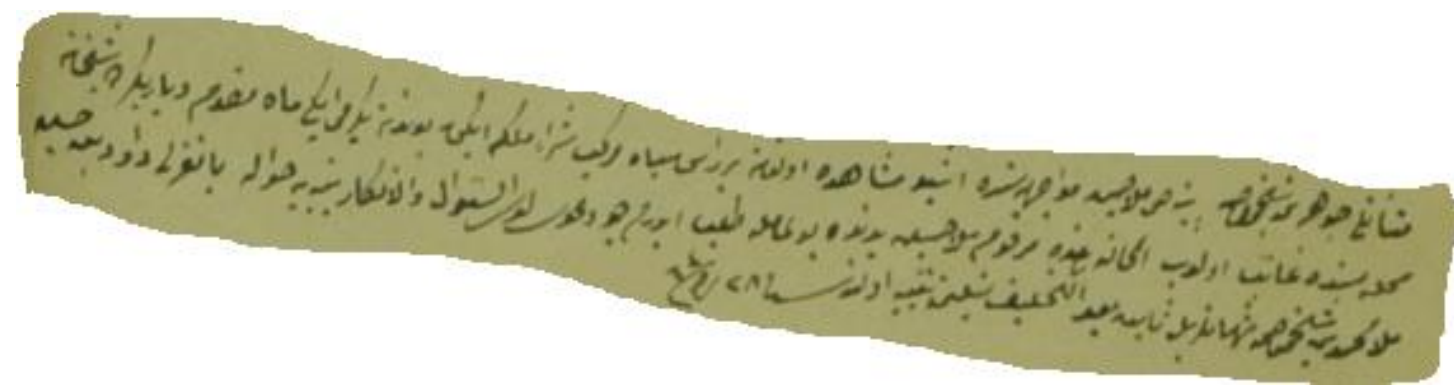

Belge 7: Penbeci Molla Hüseyin'de bulunan merkebin kendisine ait olduğunu iddia eden Cevher b. Şeyhmus'a, iddiasını ispatladığından mezkûr hayvanın teslim edilmesine hükmolunması (DŞS, 3803, 35b-6) 